\title{
Dynamic Soil Properties for Seismic Ground Response Studies in Northeastern India
}

\author{
Pradeep Kumar Dammala ${ }^{1}$, Murali Krishna Adapa $^{2}$, Subhamoy Bhattacharya ${ }^{3 *}$, George \\ Nikitas $^{4}$, Mehdi Rouholamin ${ }^{5}$
}

${ }^{1}$ Commonwealth Scholar, University of Surrey, Guildford, United Kingdom, GU2 7XH and Research Scholar, Indian Institute of Technology Guwahati, India - 781039, p.dammala@surrey.ac.uk, dammala@iitg.ernet.in

${ }^{2}$ Associate Professor, Indian Institute of Technology Guwahati, India - 781039, amurali@iitg.ernet.in

${ }^{3}$ Chair Professor \& Director SAGE Laboratory, University of Surrey, Guildford, United Kingdom - GU2 7XH, s.bhattacharya@surrey.ac.uk

${ }^{4}$ Research Scholar, University of Surrey, Guildford, United Kingdom - GU2 7XH, g.nikitas@surrey.ac.uk

${ }^{5}$ Teaching Fellow, University of Portsmouth, Guildford, United Kingdom - PO1 2UP, mehdi.rouholamin@port.ac.uk

Corresponding author:

Professor Subhamoy Bhattacharya

Chair in Geomechanics

Department of Civil and Environmental Engineering

University of Surrey

GU2 7XH

Email: S.Bhattacharya@surrey.ac.uk 


\section{ABSTRACT:}

Stiffness and damping properties of soil are essential parameters for any dynamic soil structure interaction analysis. Often the required stiffness and damping properties are obtained from the empirical curves. This paper presents the stiffness and damping properties of two naturally occurring sandy soils collected from a river bed in a highly active seismic zone in the Himalayan belt. A series of resonant column tests are performed on the soil specimens with relative densities representative of the field and with varying confining pressures. The results are compared with the available empirical curves. Furthermore, a ground response analysis study is also carried out for a bridge site in the region using both empirical curves and experimentally obtained curves. It has been observed that the application of empirical modulus and damping curves in ground response prediction often leads to underestimation of the seismic demands on the structures.

Key words: Shear modulus; Damping ratio; Resonant Column; Hyperbolic model

\section{INTRODUCTION}

India is one of the most active seismic countries in the world, particularly the North and Northeastern parts due to the Himalayan seismic belt. Assam (see Fig. 1 a), one of the seven Northeastern states of India, witnessed two great earthquakes (moment magnitude, $M_{w}>8.0$ ) and many large earthquakes $\left(6.0<M_{w}<8.0\right)$ since the first instrumentally recorded seismic event in 1897. Figure 1 (a) presents the past seismic events in and around India along with the seismic faults and seismic history in Northeast India. Bureau of Indian standards [21] classified Assam as seismic Zone $\mathrm{V}$, which is considered as one of the highest seismic zones in the world. The mighty Brahmaputra River, the widest river in Asia, flows through Assam and many lifeline structures like road and railway bridges were constructed on this river even before the first seismic code development in India. Due to the rapid urbanization and population growth, several such bridges are proposed on this mighty river. Figure 1 (b) presents the location of 
major bridges on Brahmaputra River in Assam. Due to the high seismicity of this region, the seismic vulnerability assessment of these very structures is therefore needed in order to mitigate the potential loss during any future seismic event.

The design engineers need the seismic demanding forces on the structures before proceeding for any earthquake resistant design or to assess the seismic safety of existing structures. These seismic forces can be reasonably estimated with the help of Ground Response Analysis (GRA) studies and the underlying soil properties are required for such studies. In particular, variation of shear modulus and damping with strain are essential to model the soil behavior and are often considered from standard curves, see for ex. Seed and Idriss [39], Vucetic and Dobry [46], Ishibashi and Zhang [24], Darendeli [10], Vardanega and Bolton [45]. The reliability of such curves in ground response estimation is often questioned. This calls for high quality input data of stiffness and damping of soils, especially for design or safety assessment of very important structures in seismic prone regions. This paper presents such stiffness and damping variation curves for two sandy soils collected from two bridge locations in Assam (shown in Fig.1 b), and compared with the available soil curves to see the variability of the ground response. Based on the objective, this paper is structured in the following way.

1. Resonant Column (RC) tests are performed on two sands for a range of confining pressures and initial void ratios and the corresponding modulus and damping curves are plotted.

2. Experimentally obtained curves are compared with the available empirical curves.

3. A seismic site response study is performed to demonstrate the importance of having the site specific soil curves. 

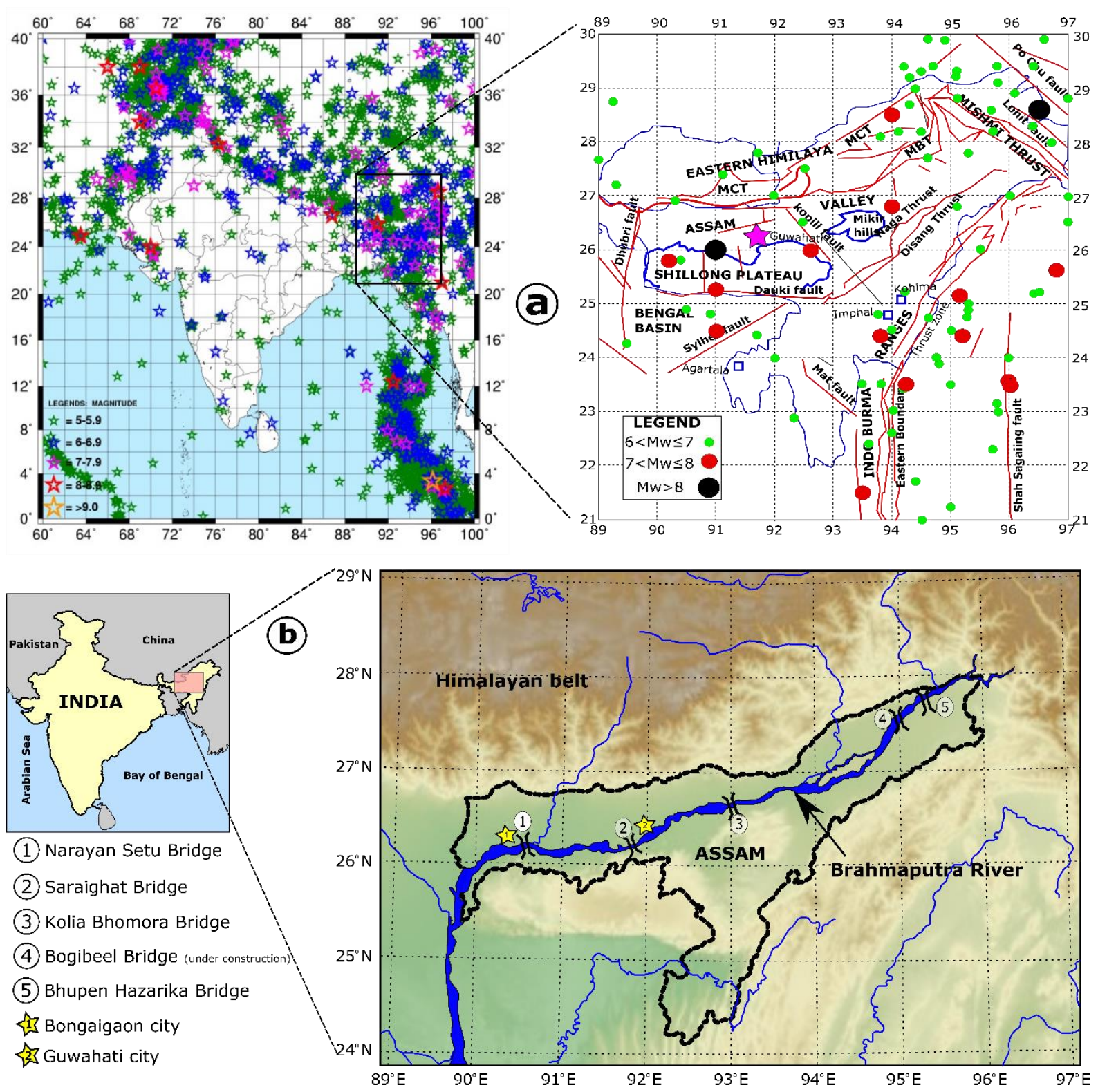

Fig. 1. (a) Seismic history of India and seismic fault details (modified after Kanth and Dash [26]) with past seismic events in Northeastern India (b) Assam state in India with the bridges on Brahmaputra River

\section{SOILS CHARACTERIZATION}

The two soils representing the typical soils from the region, are collected from the shore of the mighty Brahmaputra River (near two bridge locations shown in Fig. 1b) which flows from China towards Assam and merges in Bay of Bengal (Fig. 1 b). Standard procedures for soil sampling were followed according to Indian Standard: IS 2132 [22] and IS 10042 [23]. One of the soils is named as BP which is collected from Guwahati region near Saraighat Bridge and the other as BG, collected near Bongaigaon City. Table 1 presents the index properties of both 
the soils determined from the laboratory tests. The grain size distribution curve for both the soils is given in Fig. 2. Both the soils are classified as poorly graded (SP) fine grained sands according to the Unified Soil Classification System (ASTM D 2487 [4]). Field Emission Scanning Electron Microscopic (FESEM) pictures of both the sands can be seen in Figs. 3 (a) \& (b). It is clear from the index properties, gradation curve and the FESEM pictures that the maximum particle size of BG sand is $1 \mathrm{~mm}$ while that of $\mathrm{BP}$ sand is $0.425 \mathrm{~mm}$ and both possess similar sub-angular shape. Also both the sands can be considered as clean sands as their Fine Content (FC) is less than 5\%. The only significant difference between both the sands is the size of the particles due to which their uniformity $\left(C_{u}\right)$ and curvature coefficients $\left(C_{c}\right)$ vary.

Table 1 Index properties of both the sands

\begin{tabular}{cccccccccccc}
\hline Sand & $G_{s}$ & $e_{\max }$ & $e_{\min }$ & $\begin{array}{c}D_{10} \\
(\mathrm{~mm})\end{array}$ & $\begin{array}{c}D_{30} \\
(\mathrm{~mm})\end{array}$ & $\begin{array}{c}D_{50} \\
(\mathrm{~mm})\end{array}$ & $\begin{array}{c}D_{60} \\
(\mathrm{~mm})\end{array}$ & $C_{u}$ & $C_{c}$ & $\begin{array}{c}\text { F.C. } \\
(<75 \mu) \%\end{array}$ & $\begin{array}{c}\text { Symbol } \\
(\mathrm{USCS})\end{array}$ \\
\hline BP & 2.72 & 0.96 & 0.62 & 0.15 & 0.19 & 0.21 & 0.22 & 1.46 & 1.09 & 4.5 & $\mathrm{SP}$ \\
BG & 2.70 & 0.91 & 0.58 & 0.18 & 0.32 & 0.40 & 0.46 & 2.55 & 1.23 & 3.5 & $\mathrm{SP}$ \\
\hline
\end{tabular}

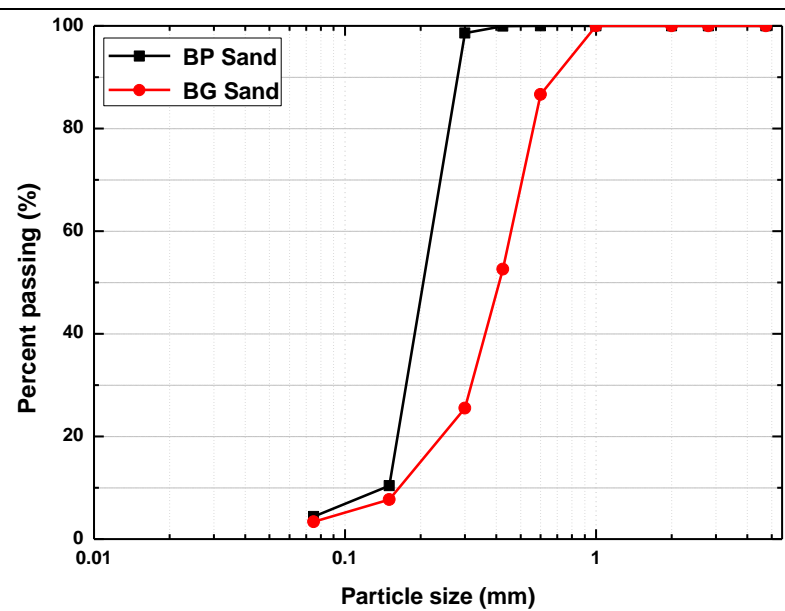

Fig. 2. Grain size distribution of both the sands

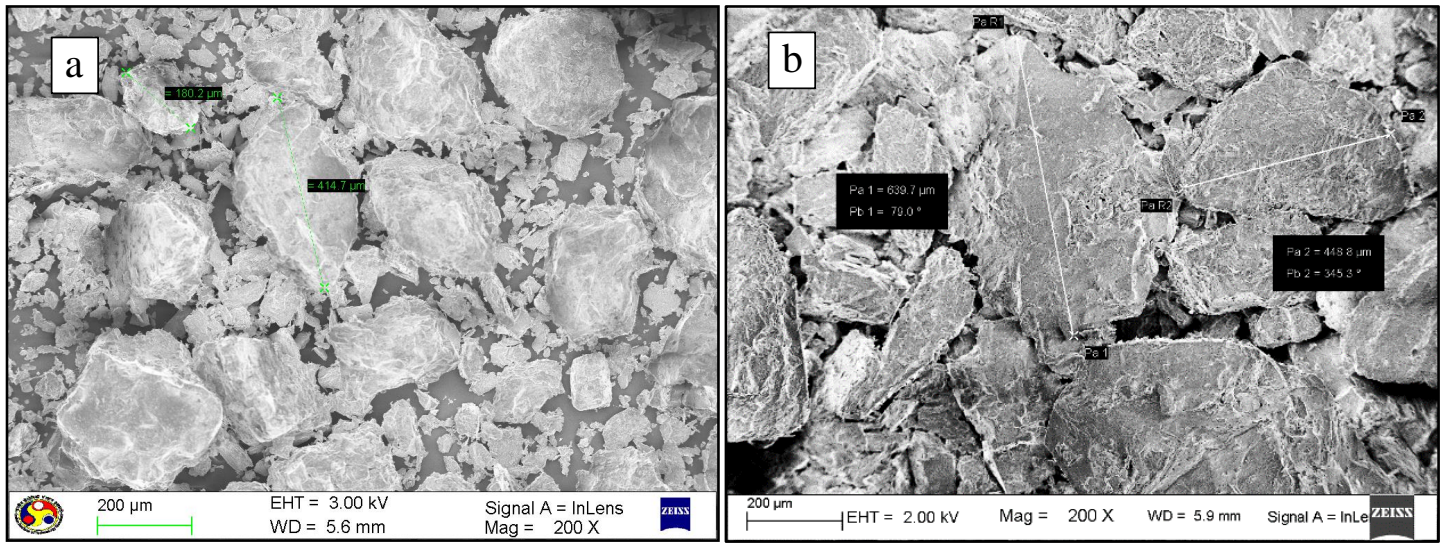

Fig. 3. FESEM images of a) BP sand and b) BG sand 


\section{TEST EQUIPMENT \& METHODOLOGY}

Laboratory tests were performed by using a fixed-free configuration of the $\mathrm{RC}$ apparatus (Fig. 4 a) available at the SAGE Laboratory, University of Surrey, UK supplied by the GDS Instruments, UK. Figure 4 (b) presents the schematic view of the RC apparatus along with some instrumentation details. The basic principle involved in RC testing is the theory of wave propagation in prismatic rods (Richart et al. [36]), where a cylindrical soil specimen is harmonically excited till it reaches the state of resonance (peak response). The testing procedures were reported in many studies (Hardin [18], Drenvich et al. [12], ASTM D 4015 [5]). Further details about the RC apparatus utilized and its calibration can be found in Cox [9].

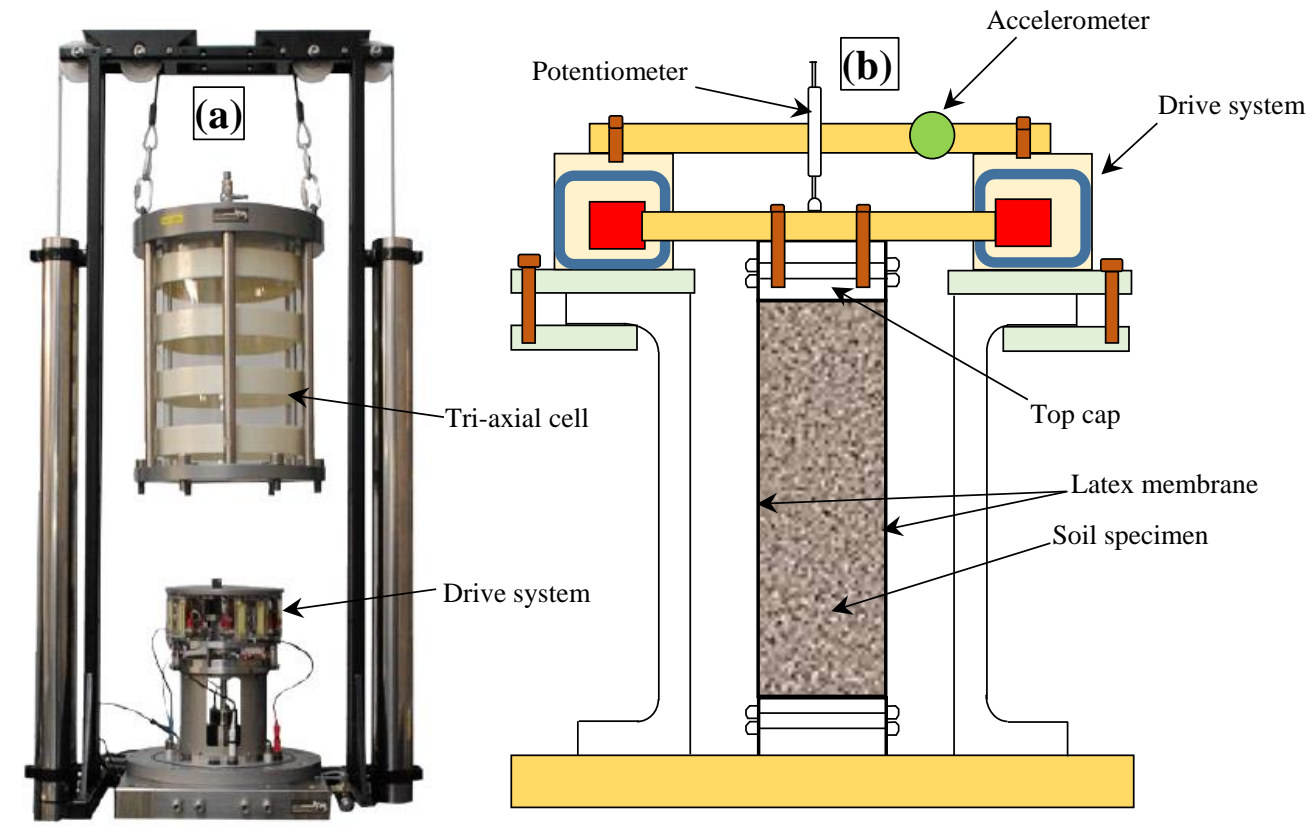

Fig. 4. (a) Photographic and (b) Schematic view of RC apparatus

\subsection{Sample preparation}

Specimen preparation was carried out as per the standards of ASTM D 4015 [5] and ASTM

D 5311 [3]. Cylindrical specimens of $50 \mathrm{~mm}$ diameter and $100 \mathrm{~mm}$ height were prepared targeting three different relative densities of loose, medium dense and dense states $(30 \%, 50 \%$ and 70\%). The sand was air pluviated using a funnel directly in to the split mould that was fitted with the latex membrane. The filling was done in four layers with each layer being compacted gently using a wooden rod giving equal amounts of tap on the sides of the mould. 
Many number of trials were performed to check the effect of height of fall and the energy given to the mould to fix the exact values so as to reach the required relative density. Once the soil specimen is ready, then the top cap is put over the sample, the latex membrane is stretched around it, and fixed using the O-rings (Fig. 4 b). The electromagnetic driving system is then carefully placed over the top cap on the specimen, levelled and fixed on the top cap with the screws provided as shown in Fig. 4 (a). Instrumentation like LVDT and accelerometer were installed after confirming the system alignment. Instrumentation is connected to the computer to record the data using the GDSLAB program (GDSLAB, 2.1.0 [14]). Table 2 summarizes the testing program and output expected in each test. 
Table 2 Tests performed on both the sands and their testing conditions

\begin{tabular}{|c|c|c|c|c|c|c|c|}
\hline S.No & Test ID & $\begin{array}{l}\text { Sand } \\
\text { type }\end{array}$ & $\begin{array}{l}\text { Relative density, } \\
\qquad \mathrm{R}_{\mathrm{d}}( \pm 2 \%)\end{array}$ & $\begin{array}{l}\text { Void } \\
\text { ratio, } e\end{array}$ & $\begin{array}{c}\text { Cell } \\
\text { pressure } \\
(\mathrm{kPa})\end{array}$ & $\begin{array}{c}G_{\max } \\
(\mathrm{MPa})\end{array}$ & $\begin{array}{l}\text { Results } \\
\text { presented }\end{array}$ \\
\hline 1 & BP1 & \multirow{12}{*}{$\begin{array}{c}\text { BP } \\
\text { sand }\end{array}$} & & 0.865 & $50 *$ & 48.49 & \multirow{9}{*}{$G-\gamma, D-\gamma$} \\
\hline 2 & $\mathrm{BP} 2$ & & 30 & 0.851 & 100 & 66.08 & \\
\hline 3 & BP3 & & $\left(e_{\text {target }}=0.860\right)$ & 0.854 & 300 & 113.96 & \\
\hline 4 & BP4 & & & 0.789 & 50 & 53.90 & \\
\hline 5 & BP5 & & 50 & 0.804 & $100 *$ & 76.57 & \\
\hline 6 & BP6 & & $\left(e_{\text {target }}=0.792\right)$ & 0.798 & 300 & 138.57 & \\
\hline 7 & BP7 & & \multirow{3}{*}{$\begin{array}{c}70 \\
\left(e_{\text {target }}=0.724\right)\end{array}$} & 0.718 & 50 & 61.28 & \\
\hline 8 & BP8 & & & 0.725 & 100 & 86.10 & \\
\hline 9 & BP9 & & & 0.712 & 300 & 166.38 & \\
\hline 10 & BP10 & & 30 & 0.856 & 50 to 600 & $52-174$ & \multirow{3}{*}{$\begin{array}{l}G_{\max } \\
D_{\min }\end{array}$} \\
\hline 11 & BP11 & & 50 & 0.780 & 50 to $600^{*}$ & $60-211$ & \\
\hline 12 & BP12 & & 70 & 0.717 & 50 to 600 & $67-218$ & \\
\hline 13 & BG1 & \multirow{12}{*}{$\begin{array}{c}\text { BG } \\
\text { sand }\end{array}$} & & 0.795 & 50 & 57.83 & \multirow{9}{*}{$G-\gamma, D-\gamma$} \\
\hline 14 & BG2 & & 30 & 0.790 & 100 & 76.58 & \\
\hline 15 & BG3 & & $\left(e_{\text {target }}=0.811\right)$ & 0.821 & $300 *$ & 160.29 & \\
\hline 16 & BG4 & & & 0.736 & 50 & 63.24 & \\
\hline 17 & BG5 & & 50 & 0.741 & 100 & 90.70 & \\
\hline 18 & BG6 & & $\left(e_{\text {target }}=0.7\right.$ & 0.748 & $300 *$ & 160.96 & \\
\hline 19 & BG7 & & \multirow{3}{*}{$\begin{array}{c}70 \\
\left(e_{\text {target }}=0.679\right)\end{array}$} & 0.680 & 50 & 76.02 & \\
\hline 20 & BG8 & & & 0.662 & 100 & 109.07 & \\
\hline 21 & BG9 & & & 0.692 & 300 & 186.35 & \\
\hline 22 & BG10 & & 30 & 0.805 & 50 to 600 & $53-194$ & \multirow{3}{*}{$\begin{array}{c}G_{\max } \\
D_{\min }\end{array}$} \\
\hline 23 & BG11 & & 50 & 0.738 & 50 to 600 & $65-229$ & \\
\hline 24 & Bg12 & & 70 & 0.678 & 50 to 600 & $72-251$ & \\
\hline
\end{tabular}

After making sure of the proper arrangement of the equipment, the triaxial cell is slowly lowered on to the resonant apparatus to allow it for confining the sample to the required initial state of the stress. The targeted confining pressure is then applied using the pressure controller in GDSLAB program. Once the targeted confining pressure is applied on to the sample, the axial deformations (if any) during the sample preparation and cell pressure application are monitored using the vertical LVDT with which the exact sample density can be calculated (reported in Table 2). It is clear from the Table 2 that the void ratio of the samples after sample preparation did not vary much (within $2 \%$ ) and can closely represent the targeted void ratio $\left(e_{\text {target }}\right)$. 


\subsection{Testing procedure}

In brief, the soil specimen is excited under a harmonic torsional vibration, induced in the form of electric voltage through the electromagnetic drive system, consisting of four magnets. Initially a small amount of electric current (say $0.001 \mathrm{~V}$ ) is passed through the magnetic coils with frequency ranging from 30 to $250 \mathrm{~Hz}$, with an increment of $5 \mathrm{~Hz}$ in order to excite the sample (typically called as broad sweeping). The frequency corresponding to the maximum amplitude of vibration is considered as the resonant frequency of the sample. Once the rough estimation of fundamental frequency at $5 \mathrm{~Hz}$ interval is completed, then a fine sweep is performed with $\pm 5 \mathrm{~Hz}$ on either side of the fundamental mode with a frequency increment of $0.1 \mathrm{~Hz}$ in order to find the exact resonant frequency of the system and the corresponding strains induced in the soil sample. Using this resonant frequency, the shear wave velocity $\left(V_{s}\right)$ and corresponding shear modulus $(G)$ of the sample is determined using wave propagation theory.

Once the resonant frequency is attained at a particular input voltage, the input current to the coils is switched off to perform a free vibration test. The response of the accelerometer with time is recorded from which the amplitude decay curve is obtained. During the free vibration decay, the effects due to the back Electro Motive Force (EMF) and instrument generated damping are reduced by providing an open circuit through the coils (GDS Instruments [13]). The peak amplitude of each cycle is determined and the corresponding damping ratio $(D)$ is evaluated as suggested by ASTM D 4015 [5]. Once the shear modulus and damping ratio at a particular strain (particular voltage) are obtained, then the input voltage to the system is further increased which in turn increases the strain in the soil specimen and the corresponding shear modulus and damping ratio are determined. Repeating the test till the strains reach $0.1 \%$ will yield in the variation of shear modulus with shearing strains. Similarly, tests to identify the initial dynamic properties (initial shear modulus, $G_{\max }$ and minimum damping ratio, $D_{\min }$ ) are also performed at different relative densities. Keeping the lowest possible voltage $(0.001 \mathrm{~V})$ 
which will induce the minimal shearing strains (strains $<0.001 \%$ ), the sample is subjected to incremental confining pressures and the corresponding low strain properties are determined as explained above.

\section{RESULTS \& DISCUSSIONS}

The typical results of $\mathrm{RC}$ tests conducted on both the sands (BP and $\mathrm{BG})$ are presented in this section. Figure 5 (a) shows the variation of shear wave velocity $\left(V_{s}\right)$ and resonant frequency $\left(f_{n z}\right)$ with confining pressure for BP sand at very low shearing strain $(<0.001 \%)$. It is obvious that the increase of cell pressure increases the shear stiffness of the soil sample. The variation of initial shear modulus $\left(G_{\max }\right)$ and small strain damping ratio $\left(D_{\min }\right)$ with the confining pressure at three relative densities for BP sand is shown in Fig. 5 (b). It is well understood from Fig. 5 that the increase in the confining pressure increases the $G_{\max }$ and decreases the $D_{\min }$ of the soil as reported by Laird and Stokoe [31] and Souto et al. [41], due to the increase in the particle contact with overburden pressure resulting in the reduction of energy dissipated. Though the decrease of $D_{\min }$ with confining pressure is obvious, no clear conclusions on the effect of relative density on $D_{\min }$ can be directly drawn due to the factors influencing the damping at low strains, such as particle rearrangement, equipment damping, and environmental noise. However, these effects become less significant at higher shear strains. Similarly, Bai (2001) noticed no significant effect of relative density/void ratio on damping ratio of Berlin sand at strains less than $1 \times 10^{-5}$.
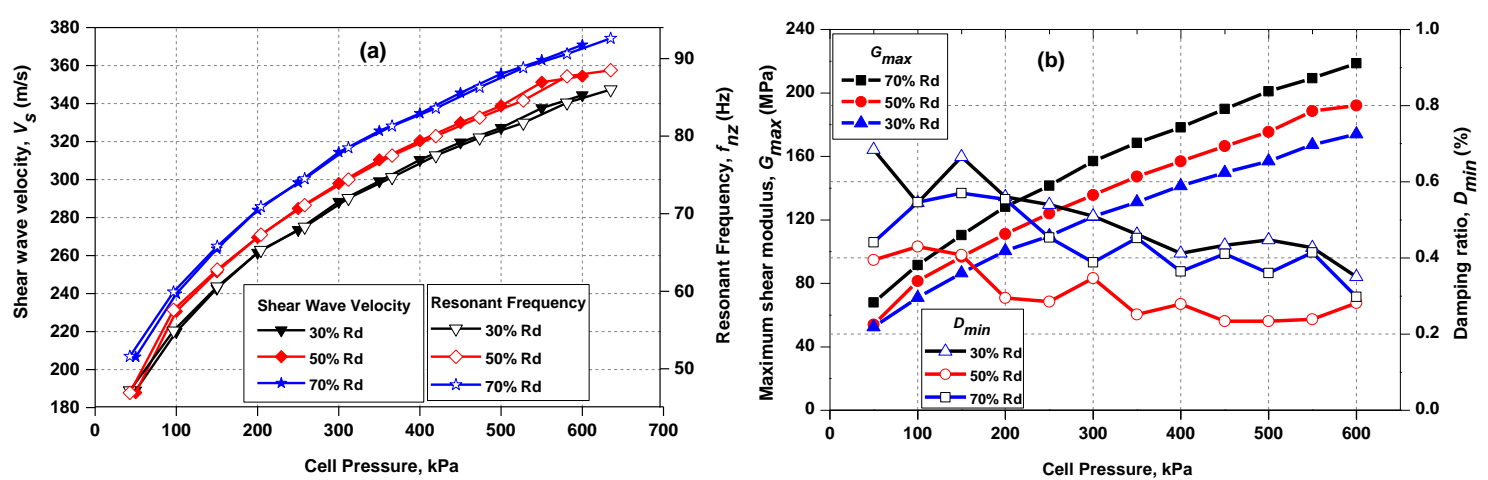

Fig. 5. (a) Shear wave velocity \& resonant frequency and (b) $G_{\max } \& D_{\min }$ variation with cell pressure for BP sand at shear strain $<0.001 \%$ 
The variation of shear modulus with shear strain for BP sand at 30\% relative density for different confining pressures is presented in Fig. 6 (a). With increase in excitation voltage, the amplitude of torsional vibration increases due to which the resonant frequency decreased causing the shear modulus to degrade. A direct proportionality between shear modulus and confining pressure is clear testifying the fact that the increase in the depth of overburden increases the dynamic shear modulus of the soil. For assessing the rate of reduction of shear modulus with the shear strain, $G$ is normalized with the initial shear modulus, $G_{\max }\left(G / G_{\max }\right)$. These curves $\left(G / G_{\max }\right)$ along with damping ratio variation for BP sand at $30 \%$ relative density for different confining pressures are presented in Fig. 6 (b). The increase in the shear strain decreased the modulus ratio and increased the damping ratio as reported in many studies. The effect of confining pressure is not much significant on the modulus reduction rate and damping ratio in the low strain range $(<0.001 \%)$ beyond which the effect is obvious. It was well documented that the increase in confining pressure decreases the modulus reduction rate of cohesionless soils (Chung et al. [8], Wichtmann and Triantafyllidis [47], Bai [6], Kokusho [28], Laird and Stokoe [31]). It is also evident from Fig. 6 (b) that the increase in the confining pressure shifts the damping curve rightwards at any given shear strain. This proves that the depth of overburden is inversely proportional to the damping ratio of the soil up to the strains considered.
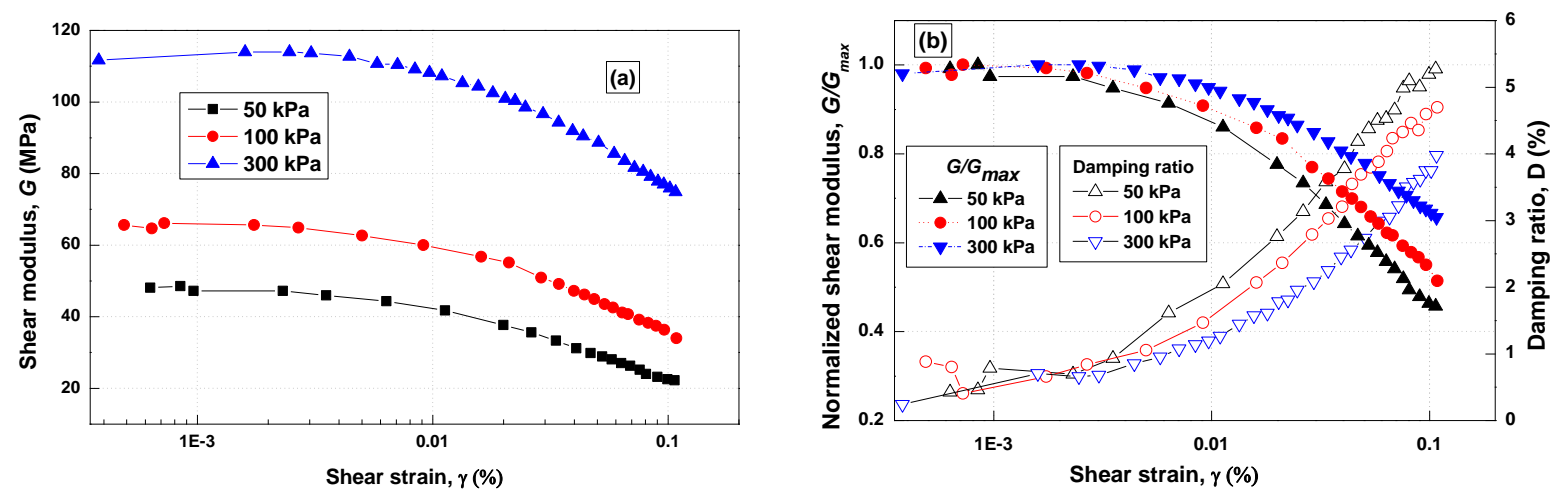

Fig. 6. Variation of (a) Shear modulus (b) Modulus degradation and damping ratio with shear strain for BP sand at $30 \% \mathrm{Rd}$

The variation of shear modulus, modulus degradation and damping ratio with shear strain for 
$\mathrm{BP}$ sand at $50 \mathrm{kPa}$ confining pressure are shown in Fig. $7 \mathrm{a}$ and b, respectively. The influence of relative density on the shear modulus is dependent on shearing strains, which becomes relatively narrow at large strains, especially at strains greater than $0.1 \%$. Similar phenomenon of less effect of relative density on the shear modulus at large strains was observed for gravels by Seed et al. [40], and for sands by Kumar et al. [29]. This suggests that the shear modulus is relatively less dependent on relative density at high shearing strains. Normalized shear modulus and damping ratio are not influenced by the relative density of the specimen (Fig. 7 b). Kokusho [28], Saxena and Reddy [38], Wichtmann and Triantafyllidis [47] and Bai [6] have also reported that the void ratio doesn't affect the modulus reduction rate and damping ratio of the sands. This could conclude that the state of the sand (whether loose or dense) would not affect the reduction rate of shear modulus and damping ratio with shearing strain as much as it is being influenced by the confining pressure. Similar trends were also observed for other confining pressures, relative densities for BP sand and also for BG sand, which are not presented here for brevity.
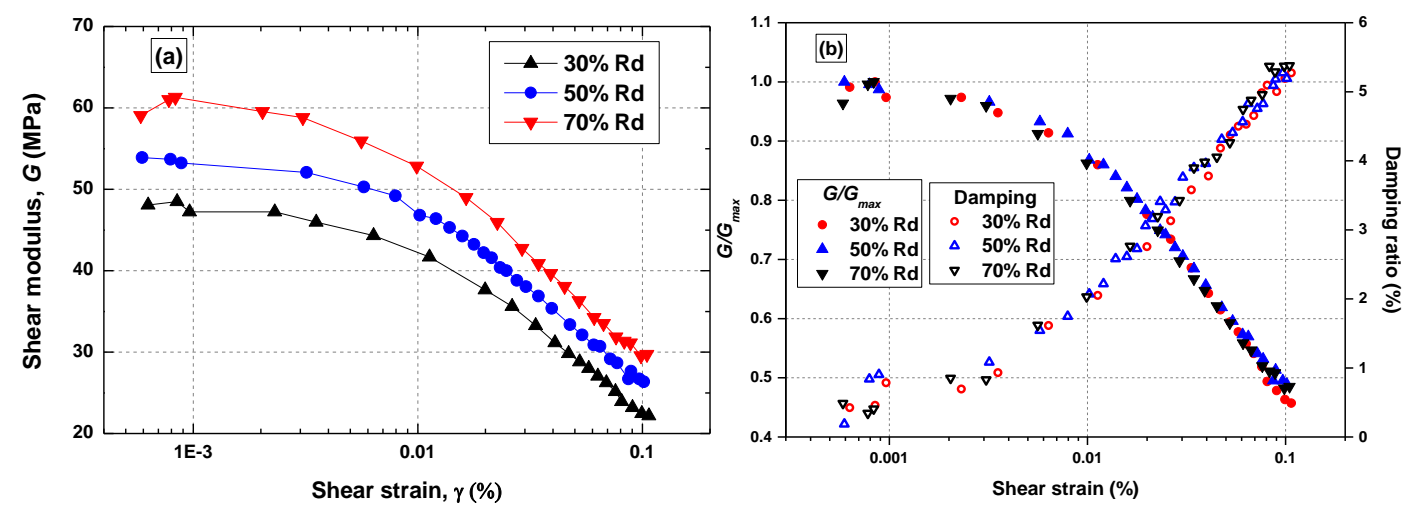

Fig. 7. Variation of (a) Shear modulus (b) Modulus degradation and damping ratio with shear strain for BP sand at $50 \mathrm{kPa}$ cell pressure

In order to compare the small strain dynamic behavior of both the sands, Fig. 8 (a) presents the variation of $G_{\max }$ with confining pressure for both the sands. Comparing the two sands, the value of $G_{\max }$ for BP sand at $50 \mathrm{kPa}$ for $30 \% \mathrm{Rd}$ is $52.4 \mathrm{MPa}$ while that of BG sand was found to be $53.5 \mathrm{MPa}$ indicating that the shear modulus is not being significantly affected by the gradation of the sand at lower confining pressures (or at surficial layers $<5 \mathrm{~m}$ deep). But with 
increase in confining pressure, a noticeable increase of $G_{\max }$ for BG sand was observed (Fig. 8 a). At $600 \mathrm{kPa}$ confining pressure, $G_{\max }$ of BG sand at $70 \% \mathrm{Rd}$ was found to be $251 \mathrm{MPa}$ while that of BP sand was $218 \mathrm{MPa}$ indicating a difference of $15 \%$. This relative increase of $G_{\max }$ for BG sand is explained by the higher uniformity coefficient compared to $\mathrm{BP}$ sand $\left(C_{u}\right.$ of $\mathrm{BG}=$ 2.55, $C_{u}$ of BP $=1.46$ ) by Menq and Stokoe [34] and Menq [33]. Figure 8 (b) presents the variation of shear modulus $(G)$ with shear strain $(\gamma)$ for both the sands at $70 \%$ relative density. It is interesting to note that the shear modulus of BG sand is relatively higher compared to that of BP sand at any given shear strain manifesting the fact that the coarseness of the soil particles increases the dynamic shear modulus at a given shear strain (Rollins et al. [37]).
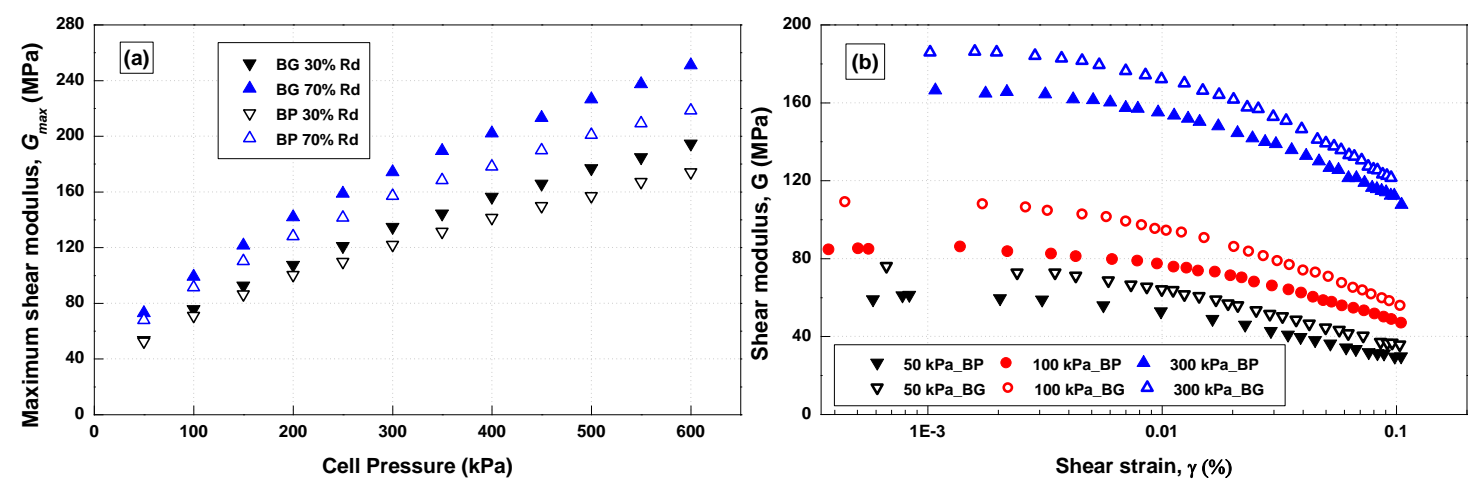

Fig. 8. (a) Maximum shear modulus with cell pressure (b) Shear modulus variation with shear strain for both the sands at $70 \%$ relative density

\section{COMPARISON WITH THE AVAILABLE MODELS}

\subsection{Maximum shear modulus $\left(G_{\max }\right)$}

For the purpose of analytical estimation of the $G_{\max }$, using the available corelations in the literature, relationship proposed by Hardin and Richart [16] for cohesionless soils has been considered (Eqn 1) for the regression analysis.

$G_{\max }=A \times F(e) \times{\sigma^{\prime}}_{m}^{0.5}$

Where $G_{\max }=$ initial shear modulus $(\mathrm{kPa}) ; \sigma^{\prime}{ }_{m}=$ effective confining pressure $(\mathrm{kPa}) ; A=$ coefficient based on the type of soil, 3227 for angular Ottawa sands (Hardin and Richart [16]); $F(e)=$ function of $e$ represented as $(2.97-e)^{2} /(1+e) ; e=$ void ratio of the sample. Figure 9 (a 
$\&$ b) present the variation of $G_{\max } F(e)$ with confining pressure for BP and BG sands respectively.
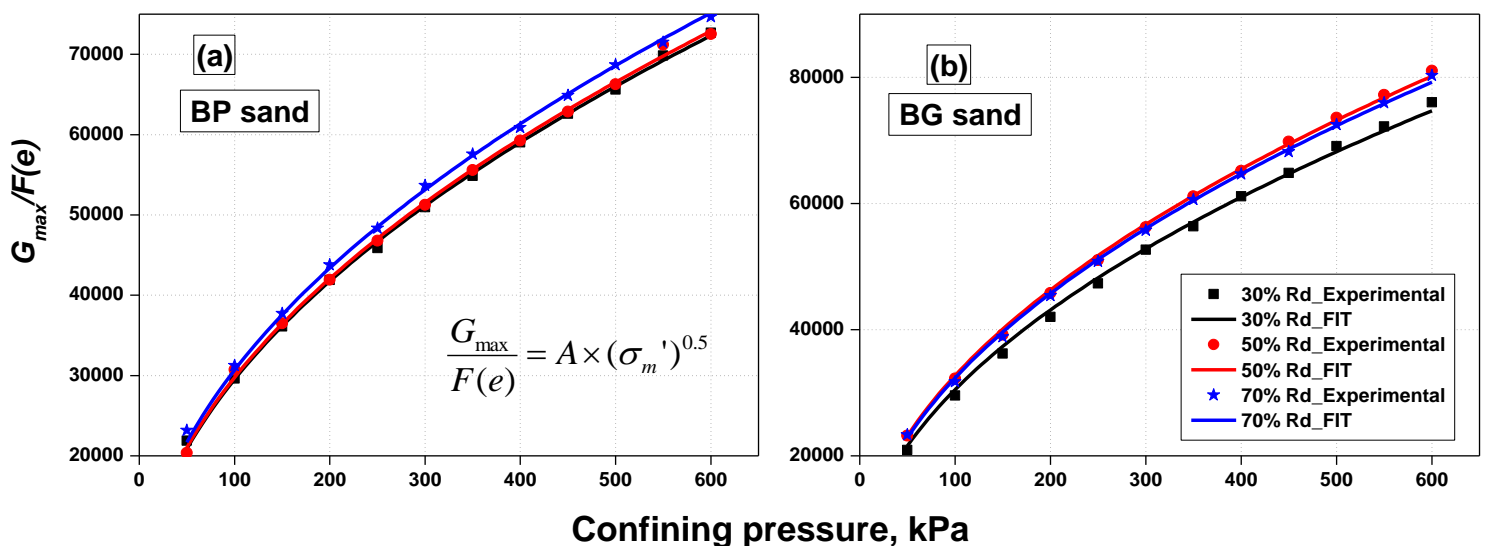

Fig. 9 Variation of $G_{\max } / F(e)$ with confining pressure for (a) BP sand (b) BG sand

Table 3 presents the values of coefficient $(A)$ for both the sands obtained from the nonlinear regression analysis of the $\mathrm{RC}$ data. It is clear that the relationship proposed by Hardin and Richart [16] can sufficiently predict $G_{\max }$ for both the sands considered, with a correlation coefficient $\left(R^{2}\right)$ of 0.99 . It is also clear from Table 3 that the value of coefficient $(A)$ for $\mathrm{BP}$ sand for any relative density considered is less than that was proposed by Hardin and Richart [16] for angular Ottawa sands (3227). The average value of $A$ for BP sand is 2998 while that of BG sand is 3184, indicating that $G_{\max }$ of both the sands are narrowly less than that of Ottawa sand.

Table 3 Values of coefficient A

\begin{tabular}{cccccc}
\hline \multirow{2}{*}{ Sand type } & \multicolumn{2}{c|}{ BP } & \multicolumn{2}{c}{ BG } \\
\cline { 2 - 6 } & & Coefficient A & $R^{2}$ & Coefficient A & $R^{2}$ \\
\hline Relative & 30 & 2952 & 0.999 & 3049 & 0.997 \\
density & 50 & 2975 & 0.998 & 3272 & 0.999 \\
$(\%)$ & 70 & 3067 & 0.998 & 3233 & 0.999 \\
\hline
\end{tabular}

\subsection{Normalized shear modulus $\left(G / G_{\max }\right)$}

Hardin and Drenvich [17] have initiated the studies on modelling the modulus degradation $\left(G / G_{\max }\right)$ based on hyperbolic relationship of shear stress and shear strain. This was later on modified by various researchers to best fit the laboratory test data, see for ex. Seed et al. [40], Ishibashi and Zhang [24], Matasovic and Vucetic [32], Rollins et al. [37], Darendeli [10], Zhang et al. [48], Vardanega and Bolton [45]. These formulations are based on the extensive 
regression analysis performed on the laboratory test results of particular type of soils with varying local soil conditions. It is therefore considered necessary to verify their applicability to the northeast Indian River bed soils. Figure 10 presents the comparison of modulus degradation of BP and BG sands with Seed and Idriss [39] limits for sands, Ishibashi and Zhang [24] for sands at $100 \mathrm{kPa}$ effective confining pressure and also the recent simplified model developed by Darendeli [10]. As can be observed, Darendeli [10] model is found to capture the response for both the sands while Seed and Idriss [39] and Ishibashi and Zhang [24] models have under estimated the modulus degradation. The effect of confining pressure is not evident from Seed and Idriss [39] curves while Ishibashi and Zhang [24] tried to correlate the confining pressure with the modulus degradation. However, stiffness degradation evaluated using Ishibashi and Zhang [24] for BP sand at $100 \mathrm{kPa}$ confining pressure seem to underestimate the values. Laird and Stokoe [31] have also observed stiffer response (higher $G / G_{\max }$ ) of sandy soils than Seed and Idriss [39] boundaries. Based on this information, the present study considers Darendeli's modified hyperbolic relationship (Eqn. 2) in order to find an optimum fit for both the soils.

$\frac{G}{G_{\max }}=\frac{1}{\left[1+\left(\frac{r}{r_{\text {ref }}}\right)^{\alpha}\right]}$

Where $\gamma=$ shear strain, $\gamma_{\text {ref }}=$ reference shear strain, shear strain at $G / G_{\max }=0.5$ and $\alpha=\mathrm{a}$ curve fitting parameter, called as curvature coefficient found to be 0.92 using Bayesian analysis (Darendeli [10]). These two parameters $\left(\gamma_{\text {ref }}\right.$ and $\left.\alpha\right)$ define or adjust the shape of the modulus degradation curve. The value of $\gamma_{\text {ref }}$ can be obtained either by performing a low strain test at a $G / G_{\max }$ value of 0.5 or evaluating it from the relationship proposed by Stokoe et al. [42] for a known confining pressure. The value of $\alpha$ can only be achieved by performing nonlinear regression analysis on the test data. 


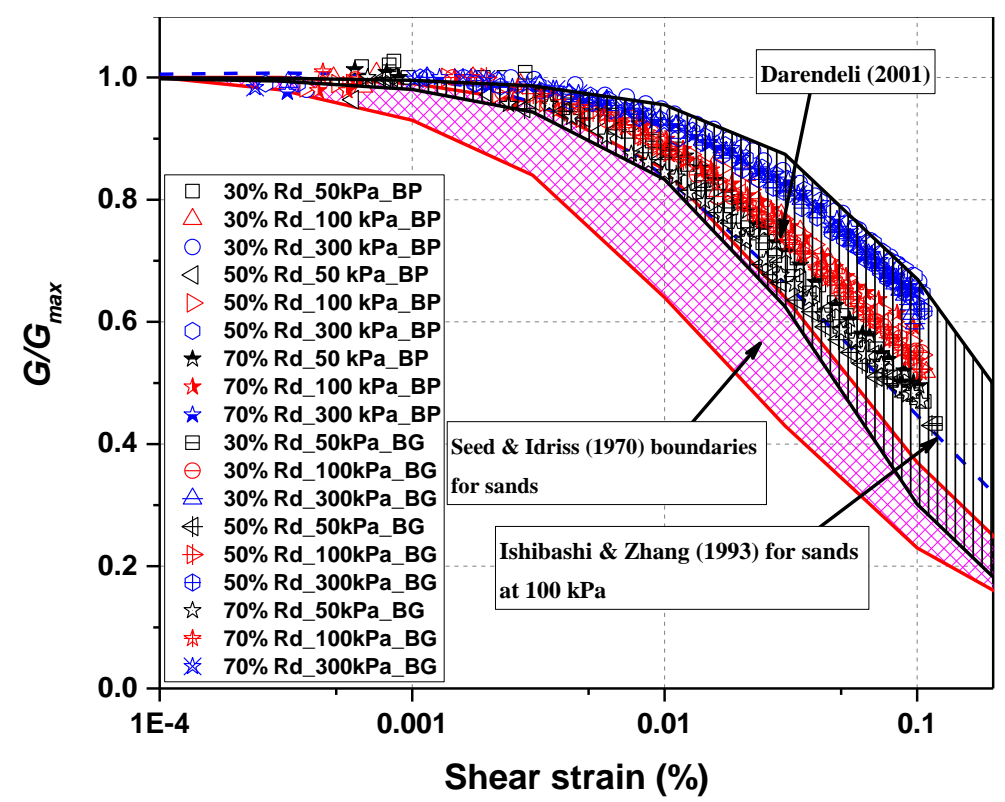

Fig. 10. Modulus reduction curves for both the sands compared with available models

For determining the best fit curvature coefficient $(\alpha)$ of the soils tested in this study, nonlinear regression analyses were performed on the RC test results of both the sands. A semi logarithmic graph presenting the linear $G / G_{\max }$ with logarithmic variation of normalized shear strain $\left(r / \gamma_{r e f}\right)$ is plotted and presented in Fig. 11. The values of reference shear strain $\left(\gamma_{r e f}\right)$ are considered from the RC test results (at $G / G_{\max }=0.5$ as suggested by Darendeli [10]). As can be observed from the Fig. 11, a parabolic variation could accurately model the entire data. Table 4 present the values of reference shear strain considered for the analysis and obtained best fitting curvature coefficient $(\alpha)$ for both the soils along with the correlation coefficient $\left(R^{2}\right)$. As it can be observed from the Fig. 11 and Table 4 that the Darendeli's model can sufficiently predict the modulus reduction rate of both the soils with almost $96 \%$ average accuracy $\left(R^{2}\right.$ ranging from 0.93 to 0.99 ). The average value of $\alpha$ for BP and BG sands for the considered $\sigma^{\prime}{ }_{m}$ is 0.937 and 0.905 respectively, which is very close to the value of 0.92 proposed by Darendeli [10], 0.70 to 1.55 proposed by Zhang et al. [48] and 0.943 proposed by Vardanega and Bolton [45].

Table 4 Curve fitting parameters for $G / G_{\max }$ and damping ratio based on modified hyperbolic formulation by Darendeli [10]

\begin{tabular}{|c|c|c|c|c|c|c|c|}
\hline \multirow{2}{*}{$\begin{array}{l}\text { Sand } \\
\text { type }\end{array}$} & \multirow{2}{*}{$\begin{array}{l}\mathrm{Rd} \\
(\%)\end{array}$} & \multirow{2}{*}{$\begin{array}{c}\text { Confining } \\
\text { pressure }(\mathrm{kPa})\end{array}$} & \multicolumn{3}{|c|}{$G / G_{\max }$} & \multicolumn{2}{|c|}{ Damping } \\
\hline & & & $\gamma_{\text {ref }}$ & $\alpha$ & $R^{2}$ & $\beta$ & $R^{2}$ \\
\hline D & 00 & 50 & 0.08 & 1.02 & 0.991 & 0.344 & 0.939 \\
\hline BP & 30 & 100 & 0.12 & 0.89 & 0.995 & 0.418 & 0.946 \\
\hline
\end{tabular}




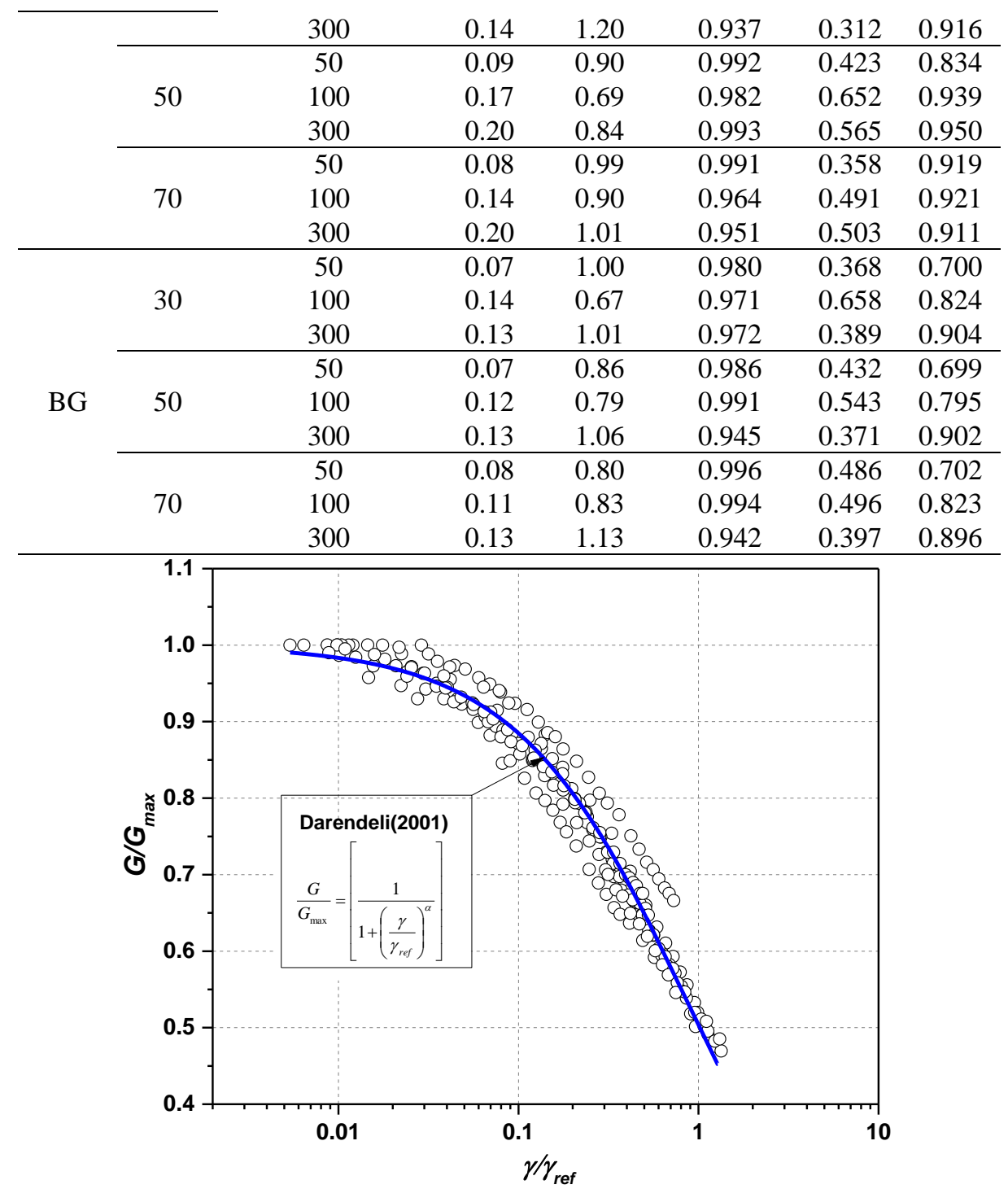

Fig 11. Variation of $G / G_{\max }$ with normalized shear strain $\left(r / \gamma_{r e f}\right)$ for both the soils

\subsection{Damping ratio}

Similar to the modulus degradation curves, analytical models were developed by many researchers for estimating the damping ratio at any given shear strain, see for example - Hardin and Drenvich [17], Seed and Idriss [39], Tatsuoka et al. [44], Ishibashi and Zhang [24], Assimaki et al [2]; Darendeli [10], Zhang et al. [48], Aggour and Zhang [1]. As explained in the earlier section, all these models were developed based on numerous experiments on particular type of soils and may not be generalized for all kinds of soils, especially while designing some lifeline structures. Figure 12 presents the comparison of damping ratio of both the sands (BP \& BG) with Seed and Idriss [39], Ishibashi and Zhang [24] and Darendeli [10] 
models. It is clear that both the sands fall below the Seed and Idriss [39] boundaries for sands which is similar to the findings of Laird and Stokoe [31] and match well with Darendeli's [10] model. A rigorous regression analysis is therefore performed on damping ratio of both the sands for all the tests to obtain the best fit parameters on utilizing the Darendeli's [10] damping model.

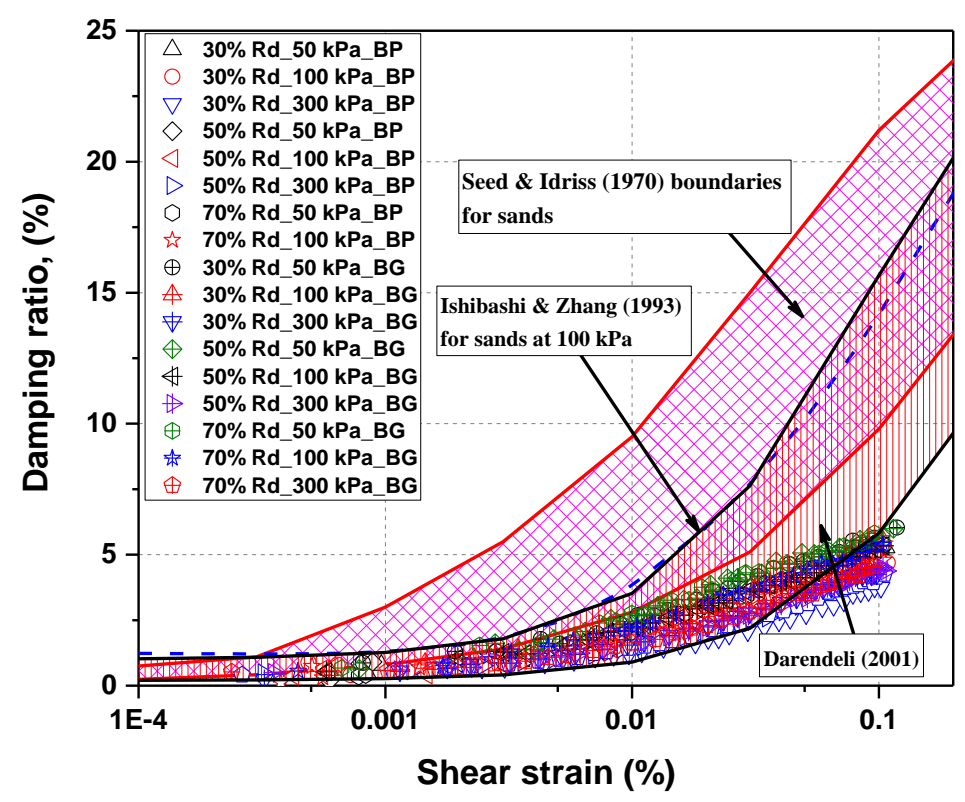

Fig. 12. Damping ratio curves for both the sands compared with available models Damping ratio $(D)$ can be expressed as a function of modulus degradation as suggested by many researchers. Based on this idea, Darendeli [10] developed a damping model (Eqn 10) based on masing behavior and related to modulus degradation using scaling coefficient $(\beta)$.

$D(\%)=\beta \times\left(\frac{G}{G_{\max }}\right)^{0.1} \times D_{\text {masing }}+D_{\min }$

Where $\beta$ is a scaling coefficient which literally is the ratio of the measured damping to the masing damping $\left(D_{\text {masing }}\right)$ at intermediate strains. The best fit values of $\beta$ for both the soils were evaluated using the regression analysis as shown in Fig. 13. The minimum damping ratio $\left(D_{\min }\right)$ is considered from the experimental results, which is in the range of $0.5 \%$ to $1 \%$ (at strains below $0.001 \%)$. Table 4 present the best fit values of scaling coefficient $(\beta)$ along with the correlation coefficient $\left(R^{2}\right)$. It can be observed from the Table 4 that the Darendeli's mathematical model is able to fit the data of both the sands, satisfactorily with an average $R^{2}$ 
value of 0.82 .

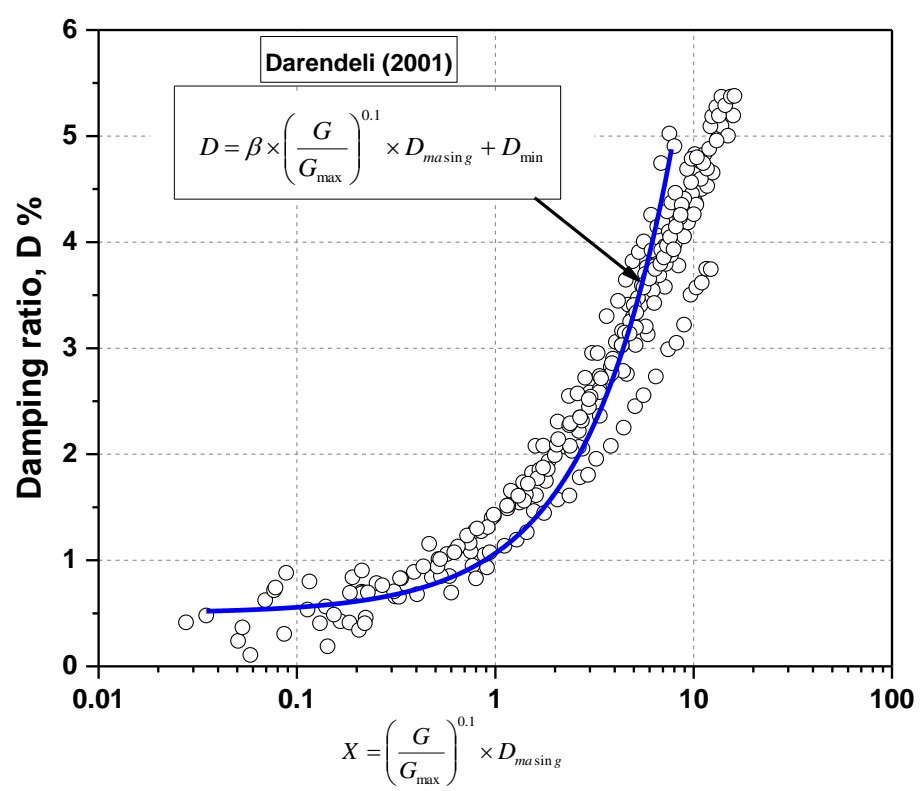

Fig. 13. Variation of damping ratio with $f\left(G / G_{\max }, D_{\text {masing }}\right)$ for both the soils

\subsection{Comparison with typical Indian cohesionless soils}

The established curves, both $G / G_{\max }$ and damping ratio with the range of proposed models along with the data of typical Indian sandy soils, have been presented in Fig. 14 and 15 respectively. Most of the data from the Indian soils (except Kansai sand data by Chattaraj and Sengupta [7]) is based on large strain dynamic testing, (either cyclic triaxial or dynamic simple shear). It is clear from Figures 13 and 14, that the established curves although based on low to intermediate strains $(0.001 \%$ to $0.1 \%)$, can model the high strain behavior satisfactorily well. An another important observation to be made from both the Figures $(14 \& 15)$ is that the low strain behavior (both modulus and damping ratio) of Kasai River sand evaluated using RC testing (Chattaraj and Sengupta [7]) is close to that of both the soils tested in this study (black solid stars in both the figures) possibly due to the close proximity (eastern Indian region). The similarity can also be justified by the close gradation properties of BP, BG and Kasai sand. Therefore, it is justifiable to conclude that Darendeli's [10] model with appropriate curve fitting parameters, may be satisfactorily used to predict the nonlinear behavior of typical northeastern Indian cohesionless soils with similar gradation properties. 


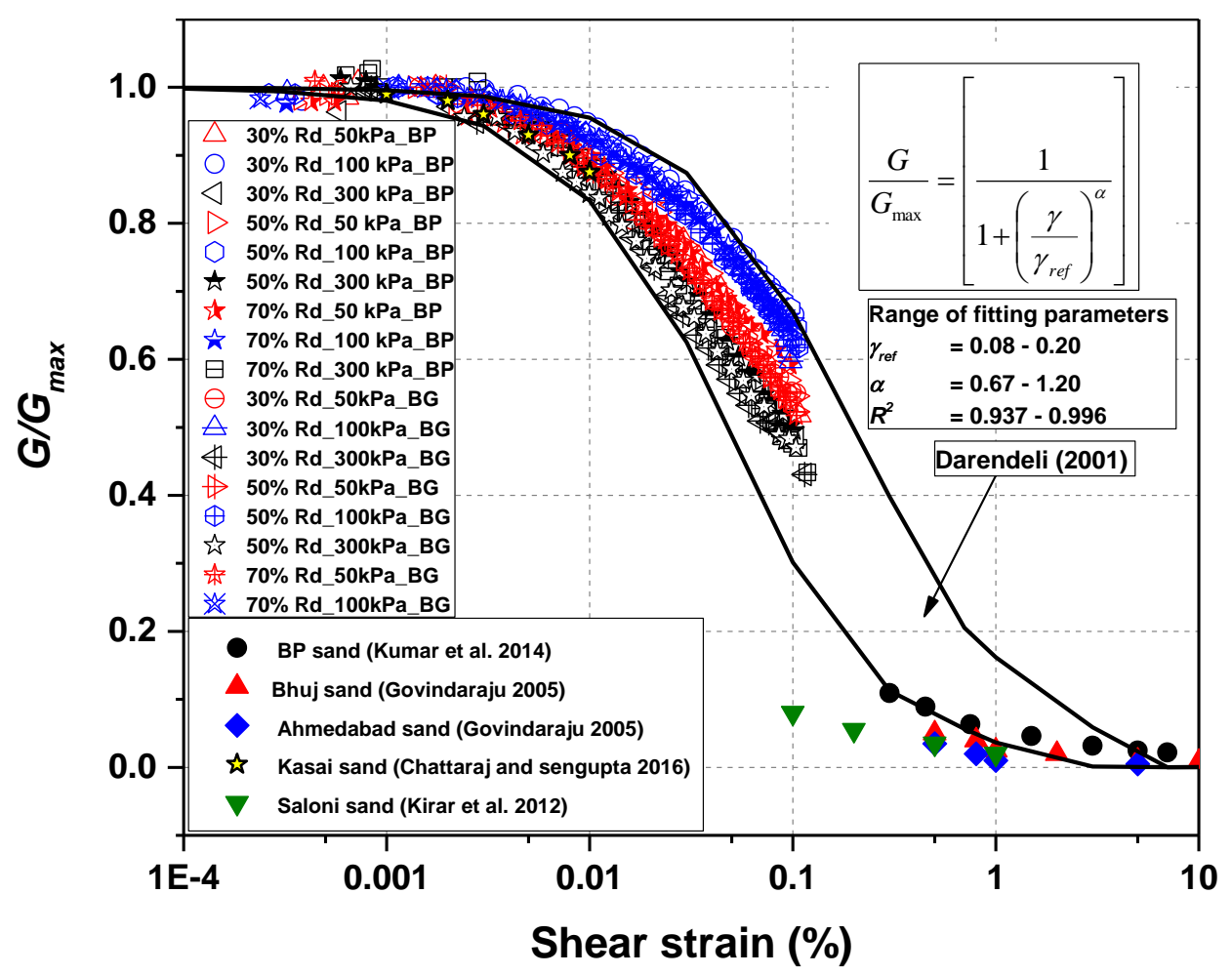

Fig. 14. Modulus degradation boundaries for both the sands with comparison to typical Indian sands

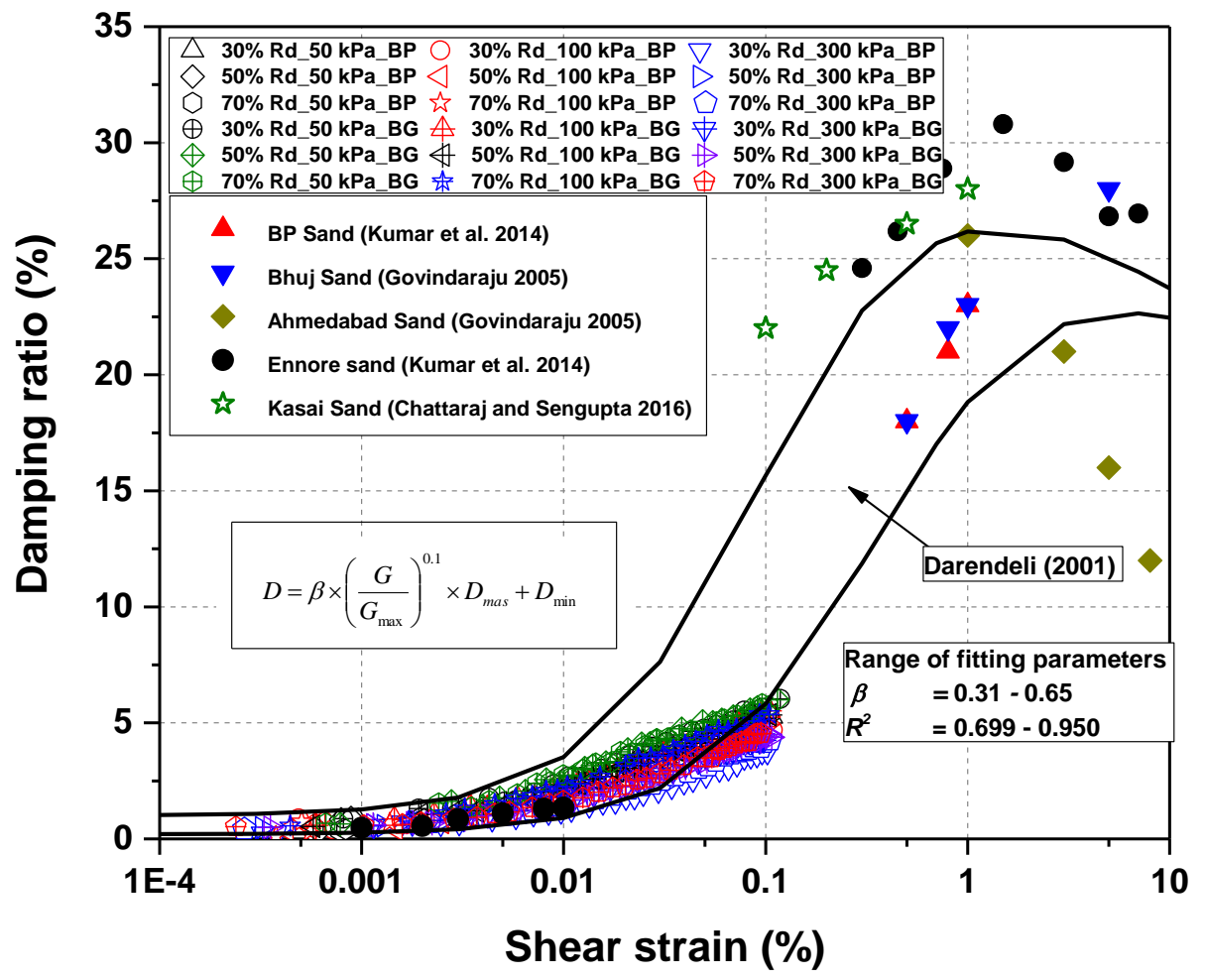

Fig. 15. Damping ratio curves for both the sands with comparison to typical Indian sands

\section{APPLICATION OF MODULUS AND DAMPING CURVES}

In order to demonstrate the effect of established curves on the seismic soil response, onedimensional (1D) equivalent linear GRA has been performed using a computer program 
DEEPSOIL V6.1 (Hashash et al. [19]). A typical soil profile in Guwahati near the center of Saraighat Bridge (location is shown in Fig. 1 b), has been chosen for the study. Details about the soil stratigraphy were obtained by soil sampling according to the Indian standard (IS 2132 [22]). Standard Penetration Tests (SPT) were conducted in the site by National Highway Authority of India (NHAI) in consultation with Gammon India limited. Table 5 shows the composite soil profile considered for the GRA study along with the appropriate soil properties for each layer. The shear wave velocity $\left(V_{s}\right)$ required for the analysis is evaluated from the relationship by Imai and Tonouchi [20] based on SPT values.

Table 5 Design soil profile in Brahmaputra River near Guwahati and corresponding parameters used for GRA study

\begin{tabular}{|c|c|c|c|c|c|c|c|}
\hline $\begin{array}{c}\text { Layer } \\
\text { No }\end{array}$ & $\begin{array}{l}\text { Soil type } \\
\text { (depth) }\end{array}$ & $\begin{array}{c}D_{i}, \\
\mathrm{~m}\end{array}$ & $\begin{array}{l}\text { SPT } \\
N_{a v g}\end{array}$ & $\begin{array}{c}V_{s}, \\
\mathrm{~m} / \mathrm{s}\end{array}$ & $\begin{array}{c}\gamma_{\text {total }}, \\
\mathrm{kN} / \mathrm{m}^{3}\end{array}$ & $\begin{array}{l}\sigma_{m-I}^{\prime}, \\
\mathrm{kPa}\end{array}$ & $\begin{array}{l}\sigma^{\prime}{ }_{m}, \\
\mathrm{kPa}\end{array}$ \\
\hline 1 & \multirow{5}{*}{$\begin{array}{l}\text { Loose fine } \\
\text { clean sand } \\
\quad(11 \mathrm{~m})\end{array}$} & 1.5 & 4 & 149 & 15.1 & 2.6 & 5 \\
\hline 2 & & 1.5 & 4 & 149 & 15.1 & 7.8 & \multirow{2}{*}{10} \\
\hline 3 & & 2 & 8 & 178 & 15.7 & 13 & \\
\hline 4 & & 3 & 8 & 178 & 15.7 & 22 & \multirow{2}{*}{25} \\
\hline 5 & & 3 & 8 & 178 & 15.7 & 33 & \\
\hline 6 & \multirow{6}{*}{$\begin{array}{l}\text { Moderate to } \\
\text { medium dense } \\
\text { fine sand }(14 \\
\text { m) }\end{array}$} & 2 & 12 & 211 & 16.2 & 42 & \multirow{2}{*}{50} \\
\hline 7 & & 3 & 15 & 226 & 16.5 & 53 & \\
\hline 8 & & 2 & 15 & 226 & 16.5 & 64 & \multirow{3}{*}{75} \\
\hline 9 & & 3 & 24 & 262 & 17.8 & 74 & \\
\hline 10 & & 2 & 24 & 262 & 17.8 & 88 & \\
\hline 11 & & 2 & 24 & 262 & 17.8 & 98 & \multirow{3}{*}{100} \\
\hline 12 & \multirow{7}{*}{$\begin{array}{l}\text { Highly dense } \\
\text { deep sand } \\
\text { partially } \\
\text { mixed with } \\
\text { greyey silt (17 } \\
\text { m) }\end{array}$} & 2 & 31 & 284 & 19.4 & 110 & \\
\hline 13 & & 3 & 31 & 284 & 19.4 & 126 & \\
\hline 14 & & 2 & 36 & 298 & 20.6 & 143 & \multirow{5}{*}{150} \\
\hline 15 & & 3 & 36 & 298 & 20.6 & 161 & \\
\hline 16 & & 3 & 36 & 298 & 21.7 & 185 & \\
\hline 17 & & 2 & 36 & 298 & 21.7 & 204 & \\
\hline 18 & & 2 & 36 & 298 & 21.7 & 220 & \\
\hline 19 & \multirow{2}{*}{$\begin{array}{l}\text { Very hard } \\
\text { deep silty clay } \\
(6 \mathrm{~m})^{*}\end{array}$} & 3 & 47 & 324 & 22.0 & \multirow[b]{2}{*}{--- } & \multirow[b]{2}{*}{--- } \\
\hline 20 & & 3 & 47 & 324 & 22.0 & & \\
\hline \multicolumn{8}{|c|}{$\begin{array}{l}D_{i}=\text { Thickness of each layer; } V_{s}=\text { shear wave velocity; } \gamma_{\text {total }}=\text { total unit weight; } \sigma^{\prime}{ }_{m-} \\
I=\text { mean effective confining pressure of } \mathrm{i}^{\text {th }} \text { layer; } \sigma_{m}{ }_{m}=\text { mean effective confining pressure } \\
\text { of entire unit; Ground Water Table }(\mathrm{GWT}) \text { is } 16 \mathrm{~m} \text { above the ground surface; }{ }^{*} \text { Clay } \\
\text { layer with PI }=85\end{array}$} \\
\hline
\end{tabular}

Ideally, each layer would have its own modulus and damping curves depending on the mean effective confining pressure of that particular layer $\left(\sigma_{m-I}^{\prime}\right)$. However, having unique curves for each layer is cumbersome and need more input data entry time. In view of this, Stokoe et al. [42] suggested that the estimated field mean effective confining pressure should be within 
about $\pm 50 \%$ of the actual values when selecting the curves for design. Therefore, chosen soil profile is divided in to seven major units (20 minor layers) with average effective confining pressure $\left(\sigma^{\prime} m\right)$ assigned for each major unit. The similar approach was used by Zhang et al. [48] for performing an equivalent linear GRA study in Charleston site. Based on this, $\sigma^{\prime}{ }_{m-I}$ for each layer is calculated assuming the coefficient of at-rest earth pressure $\left(K_{o}\right)$ to be 0.5 . The average $\left(\sigma_{m}^{\prime}\right)$ for the bigger units considered is presented in Table 6 . The reference strain $\left(Y_{\text {ref }}\right)$ to calculate $\sigma_{m}^{\prime}$ was evaluated from the relationship proposed by Stokoe et al. [42] as below.

$\gamma_{r e f}=\gamma_{\gamma 1}\left(\frac{\sigma_{m}^{\prime}}{P_{a}}\right)^{k}$

Where $\gamma_{\gamma_{1}}=$ reference strain at a mean effective confining pressure of $100 \mathrm{kPa} ; P_{a}=$ reference stress of $100 \mathrm{kPa}$; and $k=$ stress correction exponent, taken as 0.4 as proposed by Zhang et al. [45] for non-plastic soils. The obtained values of $\gamma_{r e f}$ using this relation found to match well with the experimentally obtained values of $\gamma_{r e f}$ at 50,100 and $300 \mathrm{kPa}$. The corresponding modulus curvature coefficient $(\alpha)$ and damping scaling coefficient $(\beta)$ and minimum damping ratio $\left(D_{\min }\right)$ for each layer are obtained by extra-polating the results obtained from the regression analysis on experimental results. The required modulus and damping curves for the underlying clay layer (6 m thick) were considered from Vucetic and Dobry [46]. The stratum underlying the stiff silty clay layer is a highly dense gravel with SPT N value of 110.

The input bedrock ground motions required for the analysis are chosen from stochastic seismomological model by Kanth et al. [25] in which the bedrock ground motions were developed for Guwahati city for an $8.1\left(M_{w}\right)$ earthquake in Shillong plateau in 1897. The input ground motions along with their Fast Fourier Transform (FFT) and predominant frequency $\left(f_{n z}\right)$ are shown in Fig. 16. A flexible (deformable) bedrock for the dense gravel stratum with a $V_{s}$ of $425 \mathrm{~m} / \mathrm{s}$ (based on SPT N value) was adopted for the analyses and the considered ground 
motions were applied at this stratum.
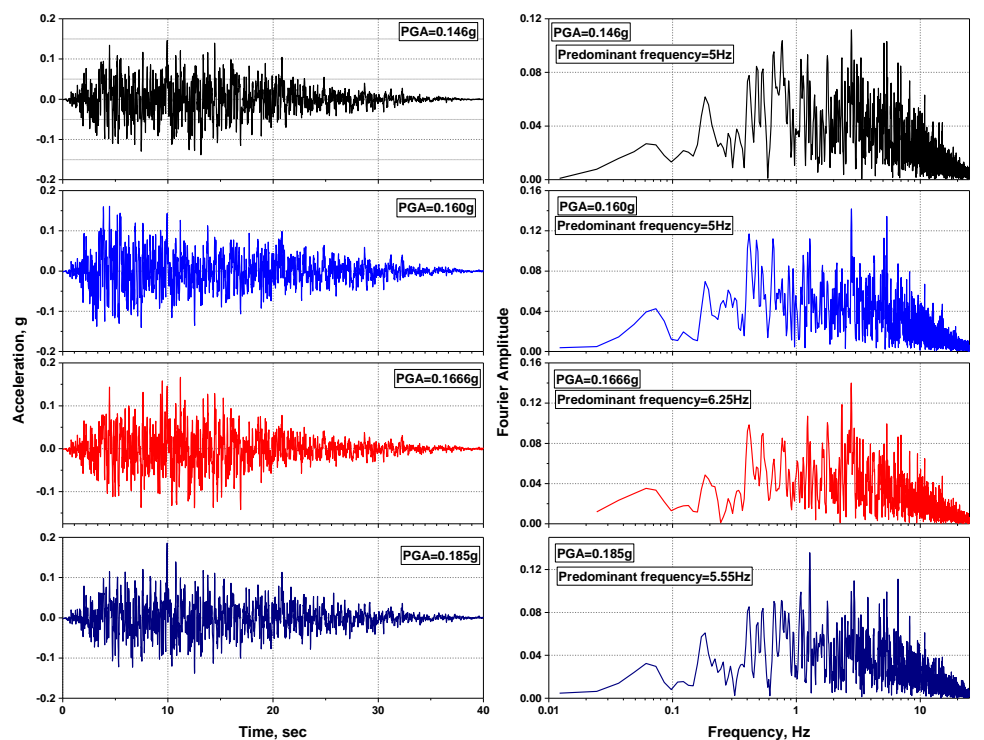

Fig. 16. Acceleration time histories and corresponding FFT of the ground motions For the purpose of comparison with the existing soil modulus and damping curves, the response of the soil is also simulated using the Seed and Idriss [39] mean sand curves, Seed and Idriss [39] different (lower curves for $\sigma^{\prime}{ }_{m} \leq 25 \mathrm{kPa}$; mean curves for $75 \leq \sigma^{\prime}{ }_{m} \geq 25 \mathrm{kPa}$; and upper curves $\left.\sigma_{m}^{\prime} \geq 100\right)$ and Darendeli [10] curves for sands. However, the behavior of the underlying clay layer is modelled using Vucetic and Dobry [46] in all the cases.

Figure 17 presents the PGA variation along the depth for different soil curves for all the ground motions considered. It is clear that the experimentally obtained curves predict higher values of PGA than the response estimated by the standard curves over the entire depth, especially in the loose surficial layers (top $10 \mathrm{~m}$ ). The PGA at the surface from the curves developed experimentally for $0.146 \mathrm{~g}$ input bedrock motion is $0.24 \mathrm{~g}$ while it is $0.171 \mathrm{~g}$ and $0.158 \mathrm{~g}$ for Seed and Idriss [39] curves and Darendeli [10] curves respectively. The similar trend of acceleration amplifications can be observed for all the ground motions considered (Fig. 17). Table 6 summarizes the surface acceleration amplifications for all the soil curves for all the ground motions considered. It is very clear from the Table 6 that the surface accelerations are being under estimated by almost 30 to $40 \%$ with the standard empirical soil curves. 


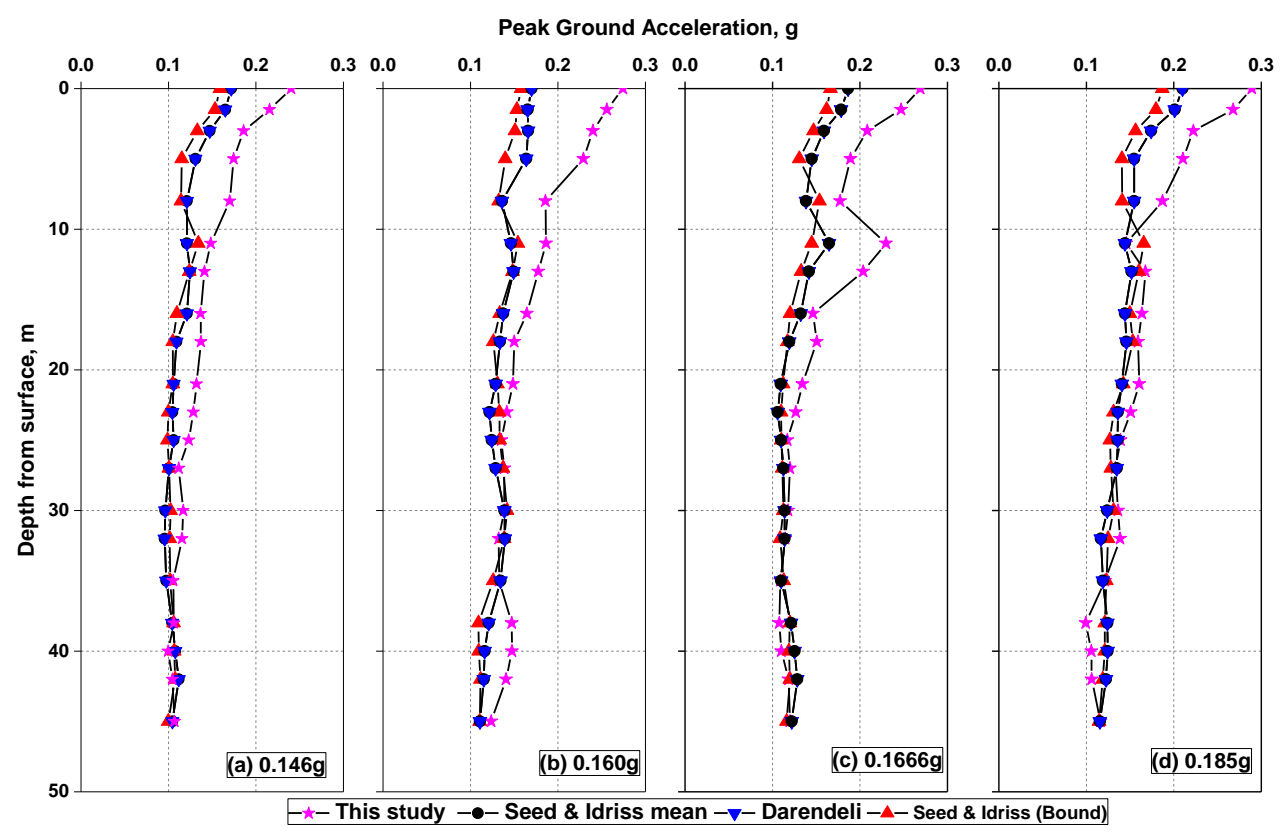

Fig. 17. Peak Ground Acceleration (PGA) variation along the depth

Table 6 Comparison of percentage difference in surface PGA using different soil curves

\begin{tabular}{cccccc}
\hline \multirow{2}{*}{$\begin{array}{c}\text { Input } \\
\text { bedrock } \\
\text { PGA, g }\end{array}$} & $\begin{array}{c}\text { Surface } \\
\text { PGA, g } \\
\text { (this study) }\end{array}$ & \multicolumn{2}{c|}{ Darendeli (2001) curves } & \multicolumn{2}{c}{$\begin{array}{c}\text { Seed \& Idriss (1970) } \\
\text { boundaries }\end{array}$} \\
\cline { 3 - 6 } & $\begin{array}{c}\text { Surface } \\
\text { PGA, g }\end{array}$ & \% difference & $\begin{array}{c}\text { Surface } \\
\text { PGA, g }\end{array}$ & \% difference \\
\hline 0.146 & 0.240 & 0.171 & -28.75 & 0.158 & -34.16 \\
0.160 & 0.274 & 0.169 & -38.32 & 0.157 & -42.70 \\
0.1666 & 0.268 & 0.186 & -30.59 & 0.166 & -38.05 \\
0.185 & 0.289 & 0.192 & -33.56 & 0.186 & -35.64 \\
\hline
\end{tabular}

In order to examine the reason for such amplification, effective shear strain profile along the depth for all the considered soil models are presented in Fig. 18. It may be observed that the soil column experienced maximum effective strains up to $0.1 \%$, with highest occuring at $10 \mathrm{~m}$ from the surface. The modulus and damping curves at $10 \mathrm{~m}$ location (at $\sigma^{\prime}{ }_{m}=25 \mathrm{kPa}$ ) for the three soil models are shows in Fig. 19. Although the strains induced in the soil column for experimentally derived curves are narrowly less than those of the other three models, at such strain levels, the soil curves considered from this study have higher modulus ratio (less nonlinearity) and lower damping values (Figs. 19) which might have caused such acceleration amplifications. 


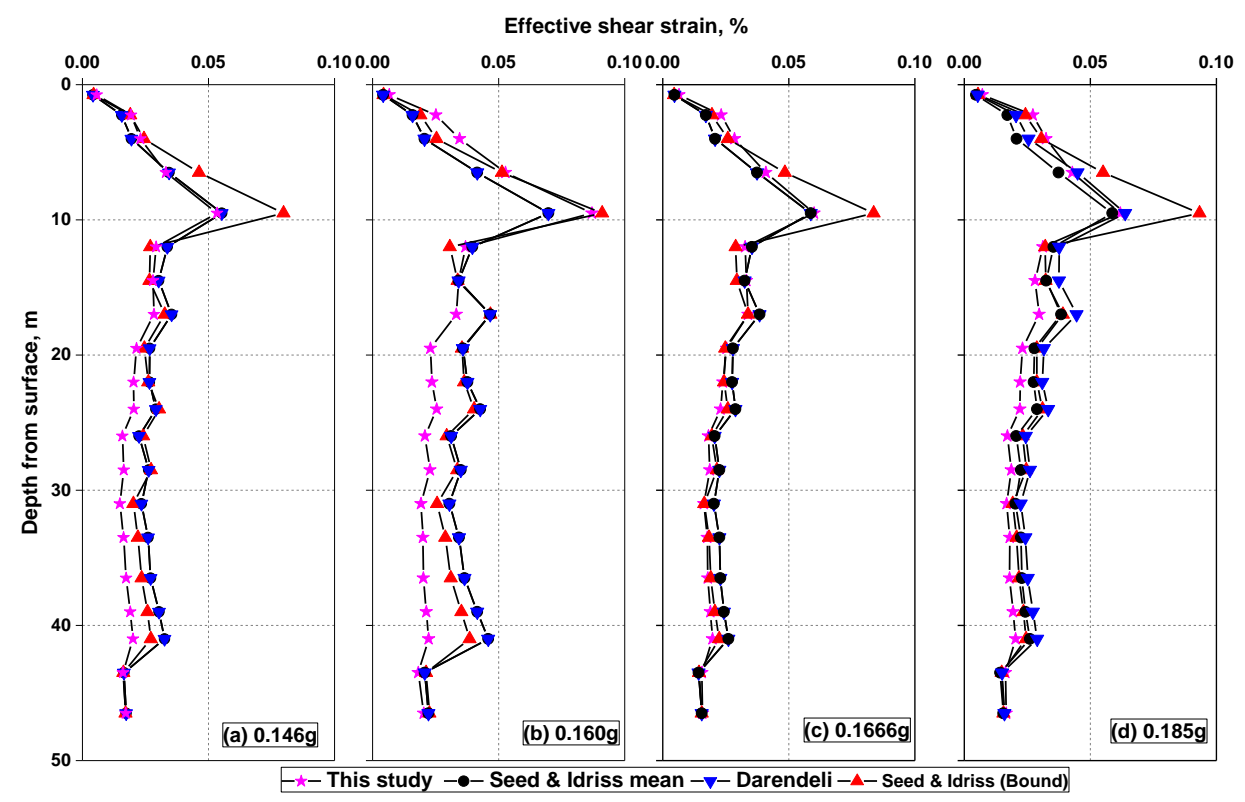

Fig. 18. Peak strain variation along the depth

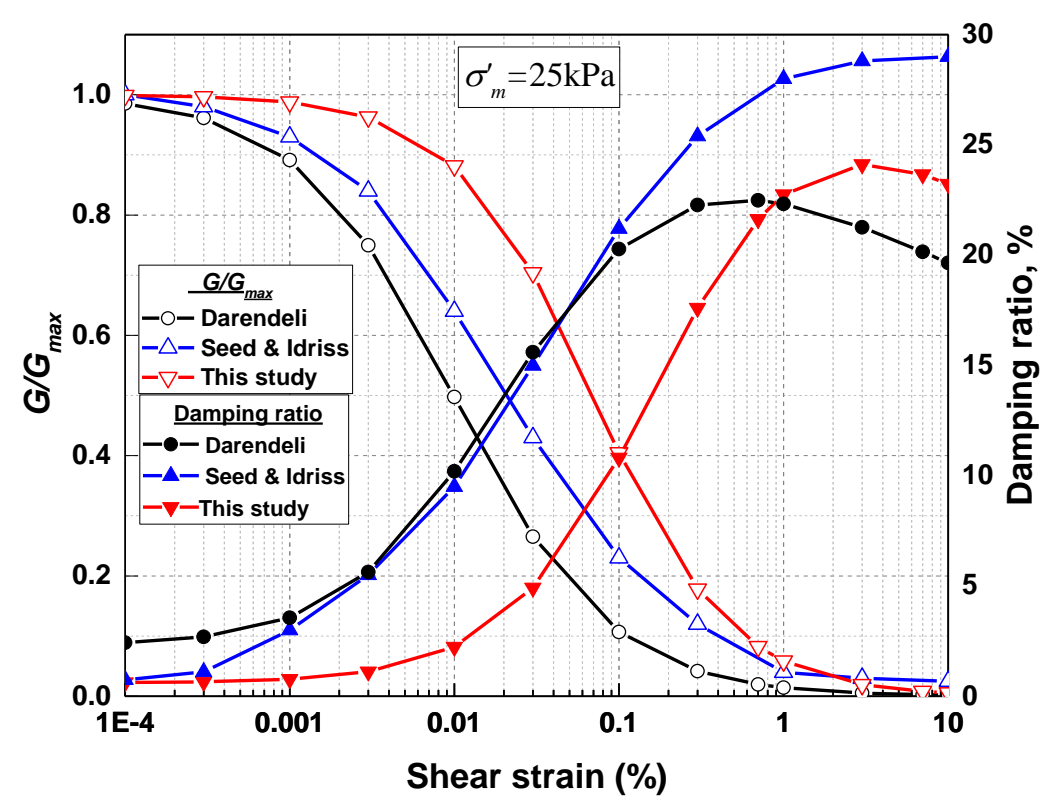

Fig. 19. Modulus degradation and damping ratio variation at $25 \mathrm{kPa}$ effective confining pressure for three soil models

Figure 20 presents the spectral accelerations at the surface using the four different modulus and damping curves for all the input ground motions considered. A similar trend of higher amplification in spectral accelerations can be observed for all the ground motions for the experimentally obtained soil curves. The higher amplifications in the PGA values and the corresponding spectral accelerations is attributed due to the wide variation in the modulus degradation and damping characterstics of the soils. 


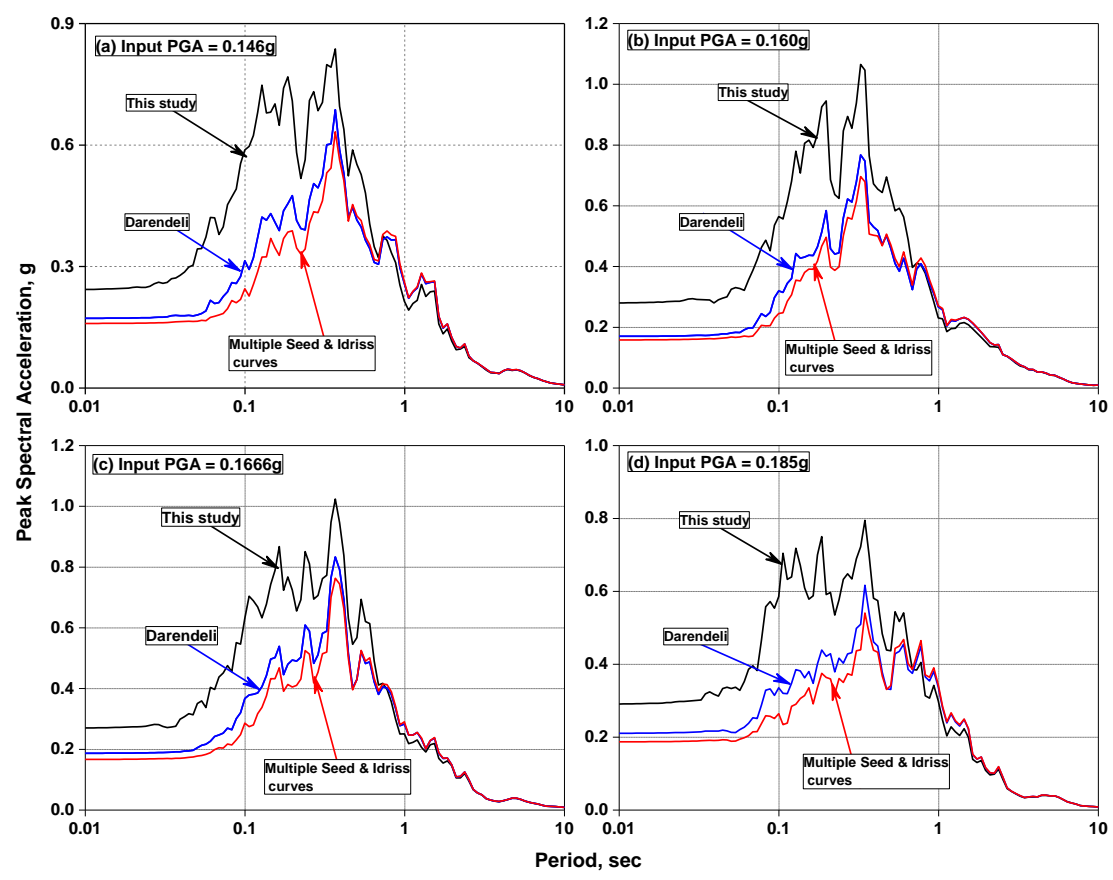

Fig. 20. Acceleration spectra at the surface for different soil curves at (a) $0.146 \mathrm{~g}$ (b) $0.160 \mathrm{~g}$ (c) $0.1666 \mathrm{~g}$ and (b) $0.185 \mathrm{~g}$ input bedrock motions

The Fourier Amplification Ratio (FAR) which is the ratio of Fourier amplitude at the surface to the bedrock amplitude is presented for all the ground motions (Fig. 21). A similar trend of increase in the amplification for experimental curves can be observed. Table 7 presents the percentage variation in FAR for the empirical curves when compared with the experimental curves. The FAR values were underestimated by both the empirical curves at least by $10 \%$. It is interesting to note that the fundamental frequencies $\left(f_{o}\right)$ are very close to that of typical bridges in the region, such as Saraighat Bridge in Guwahati. Table 8 presents the percentage difference in $f_{o}$ for the three soil models. It is clear that $f_{o}$ is under estimated by the Darendeli and Seed \& Idriss curves by approximately $20 \%$ which might render lower dynamic resistance. Hence, the significance of site specific soil curves shouldn't be neglected in GRA, especially while designing the lifeline structures. 


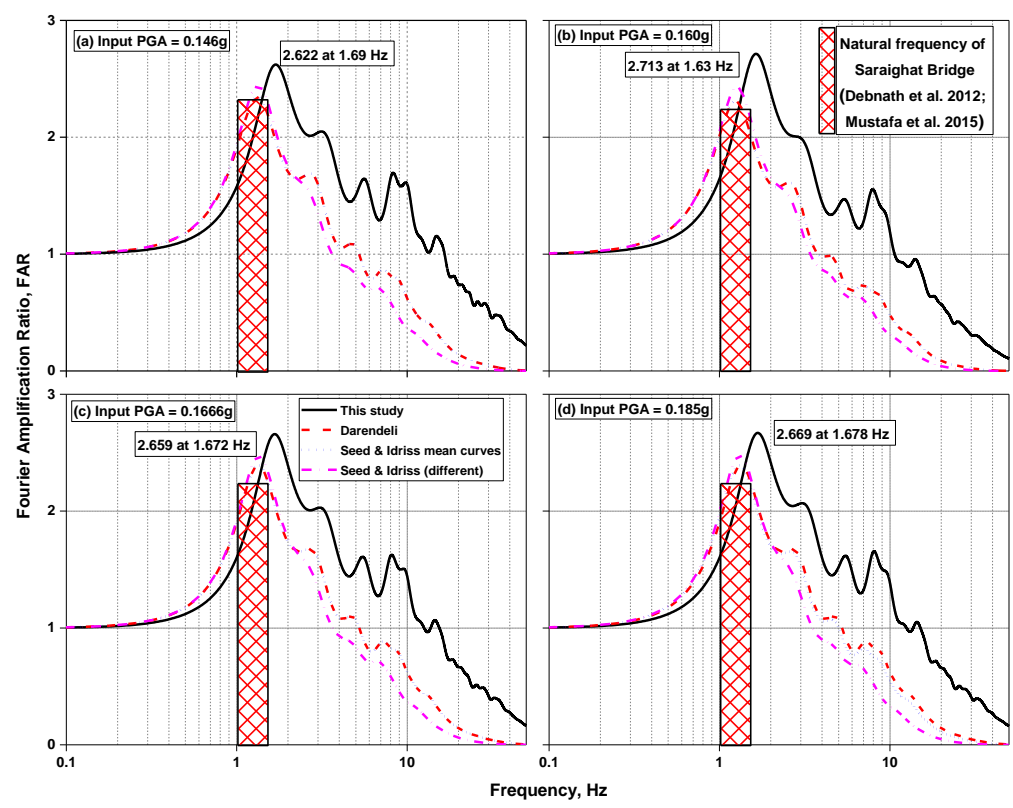

Fig. 21. Fourier Amplification Ratio (FAR) variation with frequency for different soil curves at (a) $0.146 \mathrm{~g}$ (b) $0.160 \mathrm{~g}$ (c) $0.1666 \mathrm{~g}$ and (b) $0.185 \mathrm{~g}$ input bedrock motions

Table 7 Comparison of percentage difference in FAR using different soil curves

\begin{tabular}{cccccc}
\hline \multirow{2}{*}{$\begin{array}{c}\text { Input } \\
\text { PGA, g }\end{array}$} & $\begin{array}{c}\text { FAR } \\
\text { (this } \\
\text { study) }\end{array}$ & \multicolumn{2}{c|}{$\begin{array}{c}\text { Darendeli (2001) } \\
\text { curves }\end{array}$} & \multicolumn{2}{c}{$\begin{array}{c}\text { Seed \& Idriss (1970) } \\
\text { boundaries }\end{array}$} \\
\cline { 3 - 6 } & FAR & \% difference & FAR & \% difference \\
\hline 0.146 & 2.622 & 2.346 & -10.52 & 2.449 & -6.59 \\
0.160 & 2.713 & 2.310 & -14.85 & 2.431 & -10.39 \\
0.1666 & 2.659 & 2.393 & -10.00 & 2.475 & -6.91 \\
0.185 & 2.669 & 2.392 & -10.37 & 2.481 & -7.04 \\
\hline
\end{tabular}

Table 8 Comparison of percentage difference in $f_{o}$ using different soil curves

\begin{tabular}{cccccc}
\hline \multirow{2}{*}{$\begin{array}{c}\text { Input } \\
\text { PGA, g }\end{array}$} & $\begin{array}{c}f_{o}, \mathrm{~Hz} \\
\text { (this study) }\end{array}$ & \multicolumn{2}{c|}{$\begin{array}{c}\text { Darendeli (2001) } \\
\text { curves }\end{array}$} & \multicolumn{2}{c}{$\begin{array}{c}\text { Seed \& Idriss (1970) } \\
\text { boundaries }\end{array}$} \\
\cline { 3 - 6 } & & $f_{o, H z} \mathrm{~Hz}$ & \% difference & $f_{o,} \mathrm{~Hz}$ & $\%$ difference \\
\hline 0.146 & 1.696 & 1.324 & -21.93 & 1.336 & -21.22 \\
0.160 & 1.635 & 1.245 & -23.85 & 1.269 & -22.38 \\
0.1666 & 1.672 & 1.342 & -19.73 & 1.348 & -19.37 \\
0.185 & 1.678 & 1.342 & -20.02 & 1.318 & -21.45 \\
\hline
\end{tabular}

\section{CONCLUSIONS}

Seismic design of important structures or seismic requalification of existing structures require ground response studies in order to estimate the seismic demanding forces on the structures. Design engineers often use standard empirical modulus and damping curves in order to predict the ground response and the output depends on the choice of the curves. This study presents such modulus and damping curves for two sandy soils collected from two bridge locations in Assam (a highly seismic active region in India). Resonant column tests are performed on soil 
specimens with relative densities representative of the field and with varying confining pressures. The tests were aimed to determine the small strain dynamic properties $\left(G_{\max }\right.$ and $\left.D_{\min }\right)$ along with the variation of modulus and damping with shear strain. It is concluded that the modulus degradation $\left(G / G_{\max }\right)$ increases and damping ratio decreases with confining pressure while relative density does not significantly alter these properties as reported in literature. A ground response study is performed in a bridge site in the region using one dimensional equivalent linear approach and the experimentally obtained modulus and damping curves are utilized in order to predict the soil response. Ground response is also compared using the standard modulus and damping curves such as Seed and Idriss [39] and Darendeli [10]. It is observed that the application of standard curves often results in underestimation of the peak ground accelerations and the corresponding seismic demands on the structures. The dynamic soil properties presented in this article could be particularly useful to the design engineers who would like to perform seismic ground response or seismic requalification studies in this highly active seismic region.

\section{ACKNOWLEDGEMENTS}

The research output presented in this paper was financially supported by the UK India Education and Research Initiative (UKIERI) with Reference No. UKUTP 201100296 under the joint collaboration of Indian Institute of Technology Guwahati, India and University of Surrey, UK. The funding received by the agency is fully acknowledged. The first author would like to thank Dr. Raghukanth for providing the simulated rock outcrop motions for the ground response analysis study.

\section{NOMENCLATURE}
A Coefficient for $G_{\max }$
$C_{u} \quad$ Coefficient of uniformity
$C_{c} \quad$ Coefficient of curvature
$D \quad$ Damping ratio
$D_{\min } \quad$ Minimum damping ratio
$D_{i} \quad$ Thickness of layer
$D_{\text {masing }}$ Masing damping at any given curvature coefficient
e Void ratio
$e_{\max }$ Maximum void ratio
$e_{\min } \quad$ Minimum void ratio
etarget Taget void ratio
$F(e) \quad$ Function of void ratio 
$f_{n z} \quad$ Resonant frequency

$G \quad$ Secant shear modulus

$G_{\max } \quad$ Maximum shear modulus

$G_{s} \quad$ Specific gravity of soil solids

$K_{o} \quad$ Coefficient of at-rest lateral earth pressure

$k \quad$ Stress correction factor

$M_{w} \quad$ Moment magnitude

$N_{\text {avg }} \quad$ Average Standard Penetration Test (SPT) value

$P_{a} \quad$ Atmospheric pressure

$R^{2} \quad$ Correlation coefficient

$R_{d} \quad$ Relative density

$V_{s} \quad$ Shear wave velocity

$\sigma^{\prime}{ }_{m} \quad$ Mean effective confining pressure

$\gamma_{\text {ref }} \quad$ Reference shear strain

$\gamma \quad$ Shear strain

$\alpha \quad$ Curve fitting parameter

$\beta \quad$ Scaling coefficient

$\gamma_{\text {tot }} \quad$ Total unit weight

$\sigma_{m-I}^{\prime} \quad$ Mean effective confining pressure of particular soil layer

$\gamma_{r l} \quad$ Reference shear strain at atmospheric pressure

\section{REFERENCES}

1. Aggour MS, Zhang JX. Degradation of sands due to combined sinusoidal loading. J Geotechnical and Geoenvironmental Engineering 2006; 132(12): 1628-1632.

2. Assimaki D, Kausel E, Whittle A. Model for dynamic shear modulus and damping for granular soils. J Geotechnical and Geoenvironmental Engineering 2000; 126(10):859-869.

3. ASTM Standard D-5311. Standard test method for load controlled cyclic triaxial strength of soil. West Conshohocken, Pennsylvania, USA: American Society of Testing and Materials; 2011.

4. ASTM Standard D-2487: Standard practice for classification of soils for engineering purposes (Unified Soil Classification System) .West Conshohock- en, Pennsylvania, USA: American Society of Testing and Materials; 2011.

5. ASTM Standard D-4015. Standard test methods for modulus and damping of soils by the resonant-column method. West Conshohocken, PA, USA: American Society for Testing and Materials; 2015. 
6. Bai L. Preloading effects on dynamic sand behavior by resonant column tests. PhD thesis 2011; Technischen Universität Berlin, Germany.

7. Chattaraj R, Sengupta A. Liquefaction potential and strain dependent dynamic properties of Kasai River sand. J Soil Dynamics and Earthquake Engineering 2016; 90: 467-475.

8. Chung RM, Yokel FY, Drenvich VP, Evaluation of dynamic properties of sands by resonant column testing. Geotechnical Testing J 1984; 7(2): 60-69.

9. Cox JA. Long-term serviceability behaviour of suction caisson supported offshore wind turbines. PhD Dissertation 2014; University of Bristol, UK

10. Darendeli MB. Development of a new family of normalized modulus reduction and material damping curves. PhD Dissertation 2001; University of Texas, Austin, U.S.

11. Debnath N, Dutta A, Deb SK. Placement of sensors in operational modal analysis for truss bridges. J Mechanical Systems and Signal Processing 2012; 31: 196-216.

12. Drenvich VP, Hall JR Jr, Richart FE Jr. Large amplitude vibration effects on the shear modulus of sand. Dept. of Civil Engineering, Univ. of Michigan report to U.S. Army Engineer Waterways Experiment Station, 1967; Vicksburg, Miss, on Contract No. DA-22079-eng-340NWER Subtask 13.009.

13. GDS Instruments, GDS resonant column: The GDS Resonant Column System Handbook, Global Digital Systems 2008; Hook, U.K.

14. GDSLAB 2.1.0 [Computer software]. GDS Instruments. Hook, U.K.

15. Govindaraju, L., and S. Bhattacharya. Site-specific earthquake response study for hazard assessment in Kolkata city, India. Natural hazards 61.3 (2012): 943-965.

16. Hardin BO, Richart FE Jr. Elastic wave velocities in granular soils. J. Soil Mechanics and Foundations Division 1963; Proc. ASCE, 89, No. SM1.

17. Hardin BO, Drenvich VP, Shear modulus and damping in soils: design equations and curves. J Soil Mechanics and Foundations Division 1972; 7: 667-692. 
18. Hardin BO. Suggested methods of tests for shear modulus and damping of soils by the resonant column. ASTM STP 1970; 479: 516-529.

19. Hashash YMA, Musgrove MI, Harmon JA, Groholsk DR, Phillips CA, Park D, DEEPSOIL 6.1, User Manual 2015.

20. Imai $\mathrm{T}$, Tonouchi K. Correlation of $\mathrm{N}$-value with $\mathrm{S}$-wave velocity and shear modulus. In: Proceedings of $2^{\text {nd }}$ European Symposium on Penetration Testing, Amsterdam; 1982, p. $57-72$.

21. IS 1893 (Part 1). Criteria for earthquake resistant design of structures. Bureau of Indian Standards, New Delhi, India; 2002.

22. IS 2132. Code of practice for thin-walled tube sampling of soils. New Delhi, India; 2002.

23. IS 10042. Code of practice for site investigations for foundation in gravel-boulder deposit. Bureau of Indian Standards, New Delhi, India; 1997.

24. Ishibashi I, Zhang X. Unified dynamic shear moduli and damping ratios of sand and clay. Soils and Foundations 1993; 33(1):182-191.

25. Kanth SR, Sreelatha S, Dash SK. Ground motion estimation at Guwahati city for an Mw 8.1 earthquake in the Shillong plateau. Tectonophysics 2008; 448(1): 98-114.

26. Kanth SR, Dash SK. Evaluation of seismic soil-liquefaction at Guwahati city. Environmental Earth Sciences 2010; 61(2): 355-368.

27. Kirar B, Maheshwari BK, Jakka RS. Dynamic properties of Solani sand reinforced with coir fibres. Proceedings of $15^{\text {th }}$ World Conference on Earthquake Engineering 2012; Lisboa.

28. Kokusho T. Cyclic triaxial test of dynamic soil properties for wide strain range. Soils and Foundations 1980; 20(2): 45-60.

29. Kumar SS, Krishna AM, Dey A. Parameters influencing dynamic soil properties: a review treatise, International $\mathbf{J}$ of Innovative Research in Science Engineering and Technology, 
Special Issue on National Conference on Recent Advances in Civil Engineering 2013; 3(4):47-60.

30. Kumar SS, Dey A, Krishna AM. Equivalent linear and nonlinear ground response analysis of two typical sites at Guwahati city, Proceedings of Indian Geotechnical Conference 2014; December 18-20, Kakinada, India.

31. Laird JP, Stokoe KH. Dynamic properties of remolded and undisturbed soil samples test at high confining pressure. Geotechnical Engineering Report GR93-6, Electrical Power Research Institute 1993; Palo Alto, California.

32. Matasovic N, Vucetic M. Cyclic characterization of liquefiable sands. J. Geotechnical Engineering 1993; 119(11): 1805-1822.

33. Menq FY. Dynamic properties of sandy and gravelly soils. PhD Dissertation, University of Texas 2003, Austin.

34. Menq FY, Stokoe KH. Linear dynamic properties of sandy and gravelly soils from largescale resonant tests. Di Benedetto et al., editor 2003; Deformation Characteristics of Geomaterials, 63-71.

35. Mustafa S, Debnath N, Dutta A. Bayesian probabilistic approach for model updating and damage detection for a large truss bridge. International Journal of Steel Structures $2015 ; 15(2): 473-485$.

36. Richart FE, Hall JR, Woods RD, Vibrations of soils and foundations. Prentice hall 1970, Englewood Cliffs, New Jersey.

37. Rollins KM, Evans MD, Diehl NB, Daily WD, Shear modulus and damping relationships for gravels, J. Geotechnical and Geoenvironmental Engineering 1998; 124: 396-405.

38. Saxena SK, Reddy KR, Dynamic moduli and damping ratios for Monterey no. 0 sand by resonant column tests. Soils and Foundations 1989; 29(2): 37-51. 
39. Seed HB, Idriss IM, Soil moduli and damping factors for dynamic response analyses. Report EERC 70-10, Earthquake Engineering Research Center 1970; University of California, Berkeley.

40. Seed HB, Wong RT, Idriss IM, Tokimatsu K. Moduli and damping factors for dynamic analyses of cohesionless soils. J. Geotechnical Engineering 1986; 112(11): 1016-1032.

41. Souto A, Hartikainen J, Ozudogru K. Measurement of dynamic parameters of road pavement materials by the bender element and resonant column tests, Geotechnique 1994; 44 (3): 519-526.

42. Stokoe KH II, Hwang SK, Darendeli MB, Lee NJ. Correlation study of nonlinear dynamic soils properties. Final Rep. to Westinghouse Savannah River Company 1995, Aiken, S.C.

43. Stokoe KH II, Darendeli MB, Andrus RD, Brown LT, Dynamic soil properties: laboratory, field and correlation studies. Proceedings of Second International Conference on Earthquake Geotechnical Engineering 1999; Lisbon. (3): 811-845.

44. Tatsuoka F, Iwasaki T, Takagi Y. Hysteretic damping of sands under cyclic loading and its relation to shear modulus. Soils and Foundations 1978; 18(2): 25-40.

45. Vardanega PJ, Bolton MD, Stiffness of clays and silts: Normalizing shear modulus and shear strain. J Geotechnical and Geoenvironmental Engineering 2013; 139(9): 1575-1589.

46. Vucetic M, Dobry R, Effect of Soil Plasticity on Cyclic Response. J. of Geotechnical Engineering 1991; 117(1): 89-107.

47. Wichtmann $\mathrm{T}$, Triantafyllidis $\mathrm{T}$. Influence of a cyclic and dynamic loading history on dynamic properties of dry sand, Part I: cyclic and dynamic torsional prestraining. J soil dynamics and earthquake engineering 2004; 24(2): 127-147.

48. Zhang J, Andrus RD, Juang CH. Normalized shear modulus and material damping ratio relationships. J Geotechnical and Geoenvironmental Engineering 2005; 131(4): 453-464. 